University of Nebraska - Lincoln

DigitalCommons@University of Nebraska - Lincoln

$1-2003$

\title{
Interplay of Late Cenozoic Siliciclastic Supply and Carbonate Response on the Southeast Florida Platform
}

Kevin J. Cunningham

U.S. Geological Survey, 9100 NW 36th Street, Miami, Florida 33178, U.S.A.

Stanley D. Locker

University of South Florida, College of Marine Science, St. Petersburg, Florida 33701, U.S.A.

Albert C. Hine

University of South Florida, College of Marine Science, St. Petersburg, Florida 33701, U.S.A.

David Bukry

U.S. Geological Survey, 345 Middlefield Road, Menlo Park, California 94025, U.S.A.

Laura A. Guertin

Penn State University-Delaware County, Media, Pennsylvania 19063, U.S.A.

See next page for additional authors

Follow this and additional works at: https://digitalcommons.unl.edu/usgsstaffpub

Part of the Earth Sciences Commons

Cunningham, Kevin J.; Locker, Stanley D.; Hine, Albert C.; Bukry, David; Guertin, Laura A.; and Barron, John A., "Interplay of Late Cenozoic Siliciclastic Supply and Carbonate Response on the Southeast Florida Platform" (2003). USGS Staff -- Published Research. 273.

https://digitalcommons.unl.edu/usgsstaffpub/273

This Article is brought to you for free and open access by the US Geological Survey at DigitalCommons@University of Nebraska - Lincoln. It has been accepted for inclusion in USGS Staff -- Published Research by an authorized administrator of DigitalCommons@University of Nebraska - Lincoln. 


\section{Authors}

Kevin J. Cunningham, Stanley D. Locker, Albert C. Hine, David Bukry, Laura A. Guertin, and John A. Barron 


\title{
INTERPLAY OF LATE CENOZOIC SILICICLASTIC SUPPLY AND CARBONATE RESPONSE ON THE SOUTHEAST FLORIDA PLATFORM
}

\author{
KEVIN J. CUNNINGHAM ${ }^{1}$, STANLEY D. LOCKER ${ }^{2}$, ALBERT C. HINE², DAVID BUKRY³ JOHN A. BARRON ${ }^{3}$, AND LAURA A. GUERTIN ${ }^{4}$ \\ ${ }^{1}$ U.S. Geological Survey, 9100 NW 36th Street, Miami, Florida 33178, U.S.A. \\ ${ }^{2}$ University of South Florida, College of Marine Science, St. Petersburg, Florida 33701, U.S.A. \\ ${ }^{3}$ U.S. Geological Survey, 345 Middlefield Road, Menlo Park, California 94025, U.S.A. \\ ${ }^{4}$ Penn State University-Delaware County, Media, Pennsylvania 19063, U.S.A. \\ e-mail: kcunning@usgs.gov
}

\begin{abstract}
High-resolution seismic-reflection data collected along the length of the Caloosahatchee River in southwestern Florida have been correlated to nannofossil biostratigraphy and strontium-isotope chemostratigraphy at six continuously cored boreholes. These data are interpreted to show a major Late Miocene(?) to Early Pliocene fluvialdeltaic depositional system that prograded southward across the carbonate Florida Platform, interrupting nearly continuous carbonate deposition since early in the Cretaceous. Connection of the platform top to a continental source of siliciclastics and significant paleotopography combined to focus accumulation of an immense supply of siliciclastics on the southeastern part of the Florida Platform. The remarkably thick ( $>100 \mathrm{~m}$ ), sand-rich depositional system, which is characterized by clinoformal progradation, filled in deep accommodation, while antecedent paleotopography directed deltaic progradation southward within the middle of the present-day Florida Peninsula. The deltaic depositional system may have prograded about $200 \mathrm{~km}$ southward to the middle and upper Florida Keys, where Late Miocene to Pliocene siliciclastics form the foundation of the Quaternary carbonate shelf and shelf margin of the Florida Keys. These far-traveled siliciclastic deposits filled accommodation on the southeastern part of the Florida Platform so that paleobathymetry was sufficiently shallow to allow Quaternary recovery of carbonate sedimentation in the area of southern peninsular Florida and the Florida Keys.
\end{abstract}

\section{INTRODUCTION}

The integration of marine seismic-reflection profiles and well data has been used successfully in the offshore marine environments of southern peninsular Florida to develop convincing stratigraphic models of the complex Neogene alternations of carbonate and siliciclastic sediments and rocks (Missimer and Gardner 1976; Warzeski et al. 1996; Missimer 1999). These data show the invasion of Late Miocene to Pliocene siliciclastics onto Middle Miocene to early Late Miocene carbonates at the southeastern part of the Florida Platform (Guertin et al. 2000; Cunningham et al. 2001a) and a return to carbonate deposition during the Quaternary (Enos and Perkins 1977). This study focuses on the southwestern part of the Florida peninsula (Fig. 1), an area of special interest, because it is located along a narrow north-to-south route defined by the coarsest fraction of these invasive quartz sands (Warzeski et al. 1996; Cunningham et al. 1998). This pathway was interpreted by Warzeski et al. (1996) as the palimpsest record of strong paleocurrents associated with a southward-moving shoreline and channeled deposition, or a giant prograding spit along the western side of southern peninsular Florida. These currents presumably acted to transport a huge amount of siliciclastics over the carbonate Florida Platform towards its southeastern edge during the Late Miocene and Pliocene.

In this paper we present: (1) new core and high-resolution seismic-reflection data from southwestern Florida (Fig. 1) that are interpreted to show southward transport of the siliciclastics principally via a deltaic depositional system; (2) introduce a seismic-sequence stratigraphy, nannofossil biostratigraphy, and strontium-isotope chemostratigraphy that constrain the age of this deltaic system, as well as underlying and overlying sequences; and (3) speculate on mechanisms that influenced the demise of carbonate deposition on the southeastern Florida Platform during the Miocene and Pliocene, the replacement of carbonate growth by Late Miocene to Pliocene siliciclastic deposition, and the recovery of carbonate deposition in the Quaternary. Studies of the role of siliciclastics on the initiation and expansion of carbonate platforms have been conducted on a number of different shelves and slopes (Choi and Ginsburg 1982; Choi and Holmes 1982; Davies et al. 1989; Meyer 1989; Sonnenfeld and Cross 1993; Southgate et al. 1993; Warzeski et al. 1996; Ferro et al. 1999). Our new data provide an opportunity to explore the effect siliciclastics have on rejuvenation of carbonate production on a carbonate platform.

\section{BACKGROUND}

From the Late Mesozoic to the Cenozoic, the Florida-Bahamas megabank has been one of the most expansive systems of carbonate platforms in the Earth's geologic history (Poag 1991). From the Middle Cretaceous to the Late Paleogene, a structural low called the Suwannee Strait or Gulf Trough (Hull 1962; Popenoe et al. 1987) separated the carbonate Florida Platform from a clastic shelf and slope at the southeastern part of modern North America, and was key to maintaining carbonate sedimentation on the platform (Applin and Applin 1965; Chen 1965; McKinney 1984). In the Middle Cretaceous a strong current began to flow through this low Suwannee Strait or Gulf Trough creating a sharp facies boundary between siliciclastics originating in the southern Appalachians to the north and the carbonate mega-platform to the south. Currents moving through the seaway from the Gulf of Mexico to the Atlantic precluded transport of siliciclastic sediment and nutrients from interrupting carbonate growth on the Florida Platform (Hine 1997). Development of a paleo-Florida current during the Paleocene to Early Eocene(?) weakened the current through the Gulf Trough (Denny et al. 1994), and in conjunction with inferred uplift of the Appalachian Mountains (Riggs 1979), contributed to infilling of this seaway. The Gulf Trough was closed by the Late Eocene (Chen 1965), allowing the dispersal of siliciclastics to the eastern part of the Florida Platform, where they mixed with carbonates during the Oligocene to Late Miocene (Scott 1988; Hammes 1992; Brewster-Wingard et al. 1997; Missimer 1997; Guertin et al. 2000; Cunningham et al. 2001a). Throughout the Late Miocene to latest Early Pliocene, deposition of carbonate sediments was negligible, and thick siliciclastic coastal-plain or slope deposits accumulated over most of the eastern side of the Florida Platform (Scott 1988; Cunningham et al. 1998; Missimer 1999; Cunningham et al. 2001a). Mixed carbonate and siliciclastic deposition prevailed throughout southern peninsular Florida during the latest Early Pliocene and Late Pliocene (Missimer 1992; Cunningham et al. 2001a), then carbonate deposition finally recovered with development of the well-known Quaternary carbonate shelf and shelf margin in southernmost peninsular Florida and the Florida Keys (Enos and Perkins 1977).

Late Miocene and Pliocene siliciclastics derived from the southeastern U.S. formed a bathymetric template for deposition of the Quaternary carbonate shelf and shelf margin (Jordan et al. 1964; Ginsburg et al. 1989; Warzeski et al. 1996). The timing and mechanism for long-distance transport of these quartzose sediments across the carbonate Florida Platform has 


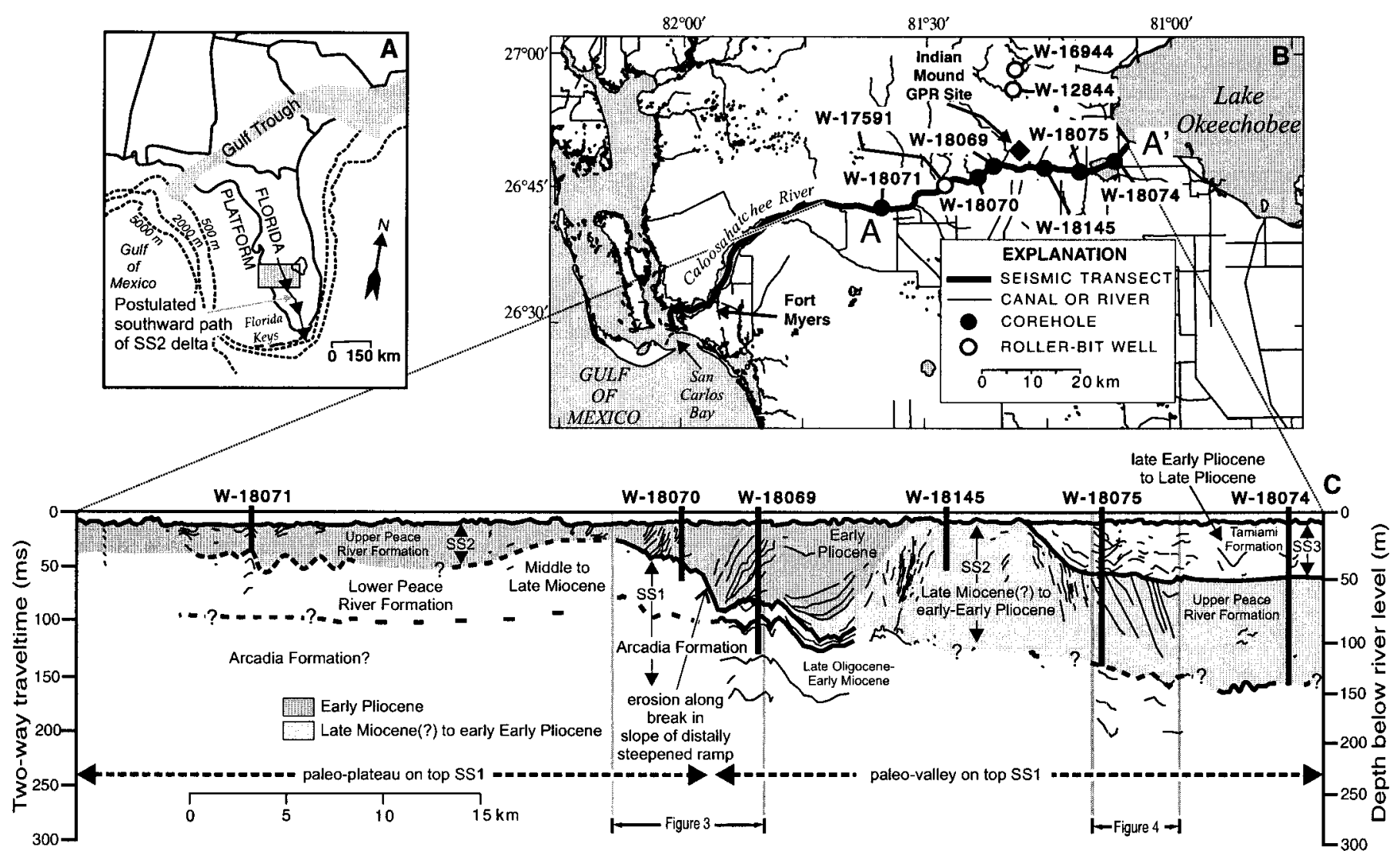

FIg. 1.-Locality of study area. A) Inset shows location of the Caloosahatchee River study area and the postulated path of a prograding axis of a Late Miocene-Early Pliocene delta (map modified from McKinney 1984). B) Inset shows location of seismic-reflection transect, ground-penetrating radar site (Indian Mound GPR site), drill sites, and cross section A-A' (Fig. 5). C) Line drawing and interpretation of high-resolution seismic-reflection data along the Caloosahatchee River in southwestern Florida, constrained by borehole data.

been open to speculation since early reports of their existence by Vaughan (1910). Bishop (1956), Klein et al. (1964), and Peacock (1983) proposed that siliciclastics were transported by a N-S oriented fluvial system with deposition in a nearshore, marine-to-brackish environment (Peck et al. 1979). Winker and Howard (1977) challenged the riverine hypothesis, wondering why a major river that presumably originated in Georgia would not take a more direct route to the sea, such as those followed by the Altamaha and Apalachicola rivers today, and instead would flow for a few hundred kilometers southward along the approximate center of an active structural arch. Alt (1974), Winker and Howard (1977), Kane (1984), and Scott (1988) concluded that siliciclastics in central Florida arrived instead by longshore transport. Ginsburg et al. (1989) suggested that the siliciclastics were transported southward to near the southern end of the Florida Platform by a combination of longshore and riverine transport, with currents and waves redistributing them to form a giant spit beneath the Florida Keys. More recently, Warzeski et al. (1996) mapped a trend of coarse-grained siliciclastics along the south-central portion of the peninsula and proposed that the coarse sands were evidence for a pathway of maximum paleocurrents. They further suggested that localized transport down the pathway was either riverine or by a huge prograding spit. Cunningham et al. (1998) revised the mapping of coarse-grained siliciclastics by Warzeski et al. (1996) and demonstrated a relationship between southward transport of the coarse-grained siliciclastics and an underlying paleotopographic low. Guertin et al. (1999) suggested that sea-level fluctuations and strong regional currents were principal controls in the erosion, transport, and winnowing of the siliciclastics.

\section{METHODS}

\section{High-Resolution Seismic-Reflection Data}

About 290 km of digital, single-channel, high-resolution seismic-reflection data were acquired using the R/V Price in 1999 over the length of the Caloosahatchee River from Lake Okeechobee extending into San Carlos Bay (Fig. 1). The seismic-reflection survey was performed using an Elics Delph2 digital acquisition and processing system, a Huntec electrodynamic "boomer" source, and an Applied Acoustics CSP-100 power supply with power settings of 700 or 1,000 J. The speed of the R/V Price was typically $6-8 \mathrm{~km} / \mathrm{hr}$. Shot rate was one second with a sampling rate of $8 \mathrm{kHz}$ and shot spacing about 2-2.5 m. An Innovative Transducer ST-5 ten-channel hydrophone array was used to detect the return pulse, and the range of the recording window was from 0 to $300 \mathrm{~ms}$. Real-time navigational positions were obtained using a differential global positioning system (GPS), and seismic shot-point positions were corrected for the offset between antenna and boomer. Post-cruise data processing included bandpass filtering with a 480-2100 Hz window; gain using a fixed baseline, plus automatic gain control with a $3 \mathrm{~ms}$ window; and trace summing by means of a three-shot moving average.

Approximate depth scales for seismic profiles were calculated from twoway traveltimes using velocities of $1,620 \mathrm{~m} / \mathrm{s}$ for relatively shallow Late Miocene to Pliocene siliciclastic sediment, and 2,500 m/s for underlying Late Oligocene to Late Miocene carbonate-dominated rocks. These velocities are based on correlation of core data (see below) to seismic profiles and indicate that with typical penetration of $250 \mathrm{~ms}$, we were imaging about 
$245 \mathrm{~m}$ of section. Description and interpretation of seismic-reflection configuration patterns are based on comparison to examples in Mitchum et al. (1977).

\section{Ground-Penetrating Radar}

Ground-penetrating radar (GPR) was used to obtain continuous images of shallow geologic units at the Indian Mound archaeological site, approximately $3 \mathrm{~km}$ north of the Caloosahatchee River, as shown in Figure 1B. All GPR data were collected using a SIR System-10A + with a dual 100$\mathrm{Mz}$ antenna array towed $17 \mathrm{~m}$ behind a truck with a connecting rope and cable at a rate of about $0.8 \mathrm{~km} / \mathrm{hr}$. The transmitter rate was 1024 samples/ scan and digital sampling rate was $20 \mathrm{scans} / \mathrm{m}$. Processing included horizontal filtering of the continuous survey data using RADAN for WinNT software. Approximate depth scales for radar profiles were calculated from two-way traveltimes employing velocities of $0.15 \mathrm{~m} / \mathrm{ns}$ for unsaturated sand and $0.06 \mathrm{~m} / \mathrm{ns}$ for saturated sand (Davis and Annan 1989).

\section{Cores}

Six 5-cm-diameter cores (533 $\mathrm{m}$ in cumulative length) were drilled continuously by the Florida Geological Survey (FGS) during 1999 to 2001 using a Failing 1500 wireline coring drill rig to constrain seismic-reflection interpretations, develop a seismic-sequence stratigraphy, and provide samples for developing a chronostratigraphy (Fig. 1). Recovery averaged approximately $75 \%$ for the six cores. Corehole sites are located no more than $100 \mathrm{~m}$ from the seismic-profiles tracks, and corehole locations were sited on seismic profiles using geographic positions acquired at the wells with a twelve-channel GPS receiver. The cores are archived in the FGS wellcutting and core repository in Tallahassee, Florida. All wells are identified by FGS ascension numbers, which have "W-" as a prefix. Detailed lithologic descriptions of the cores can be found in Cunningham et al. (2001b).

\section{Paleontology}

Coccoliths and diatoms were prepared and identified using standard methods (Barron et al. 1984) at the U.S.G.S. Micropaleontology Laboratory in Menlo Park, California. Coccolith floras were assigned to the bioistratigraphic zones of Okada and Bukry (1980) with normalized additions of Subzones CN12aA, aB, and aC from Bukry (1991). Diatom floras were dated using the zonations of Barron (1992). There was no evidence for reworking of nannofossils based on the occurrence of asynchronous species mixed together into unnatural associations, or mixing of fossils with varying degrees of preservation.

Information contained in Bock et al. (1971), Poag (1981), and Jones (1994) was used to help identify benthic foraminifera at the genus level. Paleoenvironmental interpretations are based on Murray's (1991) grouping of individual benthic foraminiferal associations and species into broad depth categories of inner and outer shelf, which are defined as mean sea level to approximate water depths of $100 \mathrm{~m}$ and 100 to $200 \mathrm{~m}$, respectively.

\section{Strontium-Isotope Chemostratigraphy}

Fourteen pelecypod shells and one echinoderm shell that appeared unaltered, on the basis of examination with a binocular microscope, were collected from coreholes W-18069, W-18070, and W-18071 for strontiumisotope analysis. Chemical separations and isotopic analyses were conducted by the Thermal Ionization Mass Spectrometry (TIMS) Laboratory at the University of Florida, Gainesville. X-ray diffraction analyses were used to determine carbonate mineralogy of samples. The within-run precision for single analyses ranged from $10 \times 10^{-6}$ to $21 \times 10^{-6}(2 \sigma$ standard error from the mean). All strontium-isotopic ratios were normalized to ${ }^{86} \mathrm{Sr} /{ }^{88} \mathrm{Sr}=0.1194$ and to SRM-987 $=0.710249$ with a $2 \sigma$ error of $23 \times 10^{-6}$. Conversion of ${ }^{87} \mathrm{Sr} /{ }^{86} \mathrm{Sr}$ values to ages was derived from

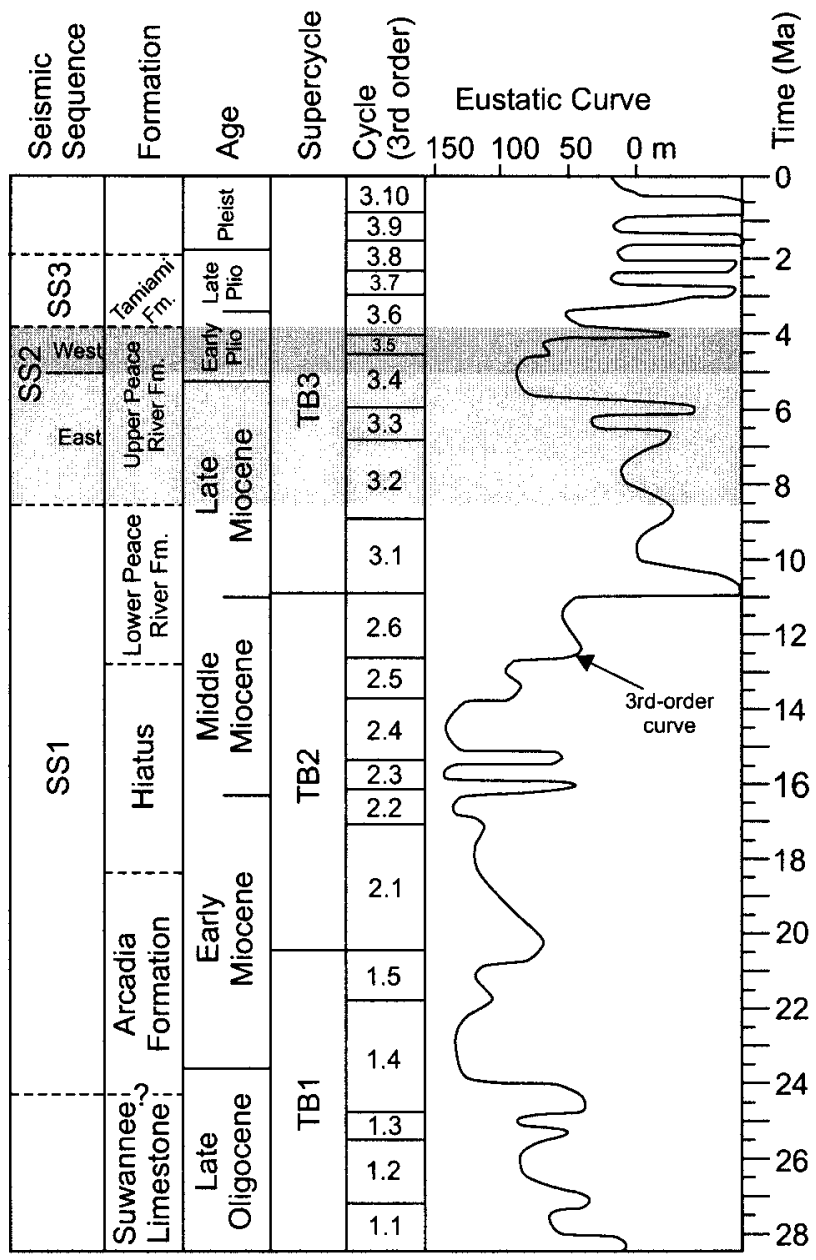

FIG. 2.-Relationship between seismic and lithostratigraphic nomenclature, sequence chronostratigraphy, and eustatic curves (Haq et al. 1988). The light and dark gray shaded areas correspond to the Late Miocene(?) to early Early Pliocene and younger Early Pliocene portions, respectively, of the deltaic depositional system shown in Figure 1.

“Look-up Table Version 3:10/99”' of Howarth and McArthur (1997). A value of $1 \times 10^{-6}$ was subtracted from all ${ }^{87} \mathrm{Sr} /{ }^{86} \mathrm{Sr}$ values to correct for an interlaboratory bias between the University of Florida values and data presented in the "Look-up Table" of Howarth and McArthur (1997). The ages are in accordance with the integrated Cenozoic magnetobiochronologic Cenozoic time scale of Berggren et al. (1995).

\section{SURFACE-GEOPHYSICAL, LITHOLOGIC, AND CHRONOSTRATIGRAPHIC CHARACTER OF SEISMIC SEQUENCES}

Below are descriptions and interpretations of the seismic character, lithology, and chronostratigraphy of three seismic sequences (SS1-SS3; Figs. 1, 2). Upper boundaries to seismic-sequences SS1 and SS2 correspond to unconformities identified in cores (Figs. 1, 3, 4, 5). Also included are GPR data collected north of the Caloosahatchee River at the Indian Mound site (Fig. 1B) that show reflections within the upper part of SS2 and possibly within SS3.

\section{Seismic Sequence 1 (SS1)}

Seismic Data.-The seismic-reflection characteristics of SS1 include a subhorizontal parallel configuration with an even to broad-wavy pattern (Figs. 3, 4). In the area of the W-18071 corehole (Fig. 1), reflections have 


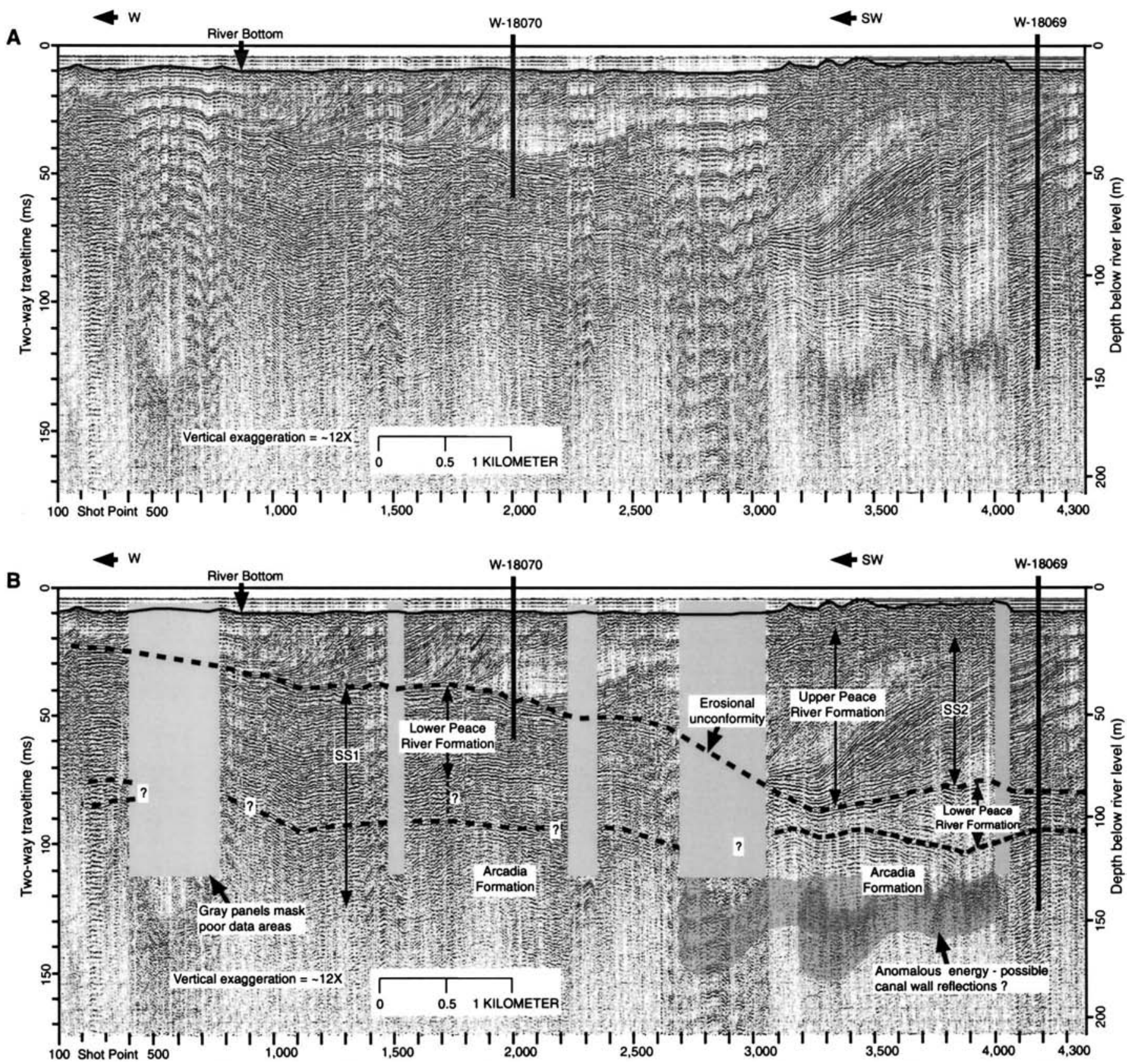

FIG. 3-A) Uninterpreted reflection-seismic profile along coreholes W-18069 and W-18070. B) Interpreted reflection-seismic profile along coreholes W-18069 and W18070. The oblique prograding reflections assigned to the upper Peace River Formation downlap onto a major seismic-sequence boundary that formed by erosional truncation along the break in slope of the distally steepened lower Peace River ramp. The parallel reflections that lie below the unconformity are assigned to the lower Peace River Formation and confirmed by corehole data. Near the W-18070 corehole, clinoformal beds of the upper Peace River Formation probably crop out at the river bottom. To aid visualization, segments of the seismic data showing poor quality are blanked out.

a parallel high-amplitude wavy pattern that may be related to the karst induced collapse of more deeply buried limestone strata. Near the W-18069 corehole (Fig. 3), the uppermost seismic reflections of SS1 are truncated, which is interpreted to represent an erosional event and development of a major seismic-sequence boundary between SS1 and SS2. Reflections of SS2 downlap onto the top of SS1 over much of the SS1-SS2 seismicsequence boundary (Figs. 1, 3, 4).

Core Data.-The lithology of SS1 includes dolosilt, lime mudstone, pelecypod floatstone and rudstone, bryozoan floatstone, quartz sand with abundant phosphorite grains, and mudstone, and matches that described from the lower Peace River and Arcadia Formations by Missimer (1997), who interpreted these formations to represent a broad, aggradational, mixed carbonate-siliciclastic ramp depositional system. This is consistent with region-wide SS1 subhorizontal parallel reflections that are typically exhibited in the seismic profiles (Figs. 3, 4). We believe the SS1-SS2 seismicsequence boundary is an erosional unconformity that can be observed in cores W-18069 and W-18070 (Fig. 6A), and corresponds to the sequence boundary that separates the lower and upper Peace River Formations (Missimer 1997; Guertin et al. 2000).

Strontium-isotope chemostratigraphy delineated for the W-18069 core 

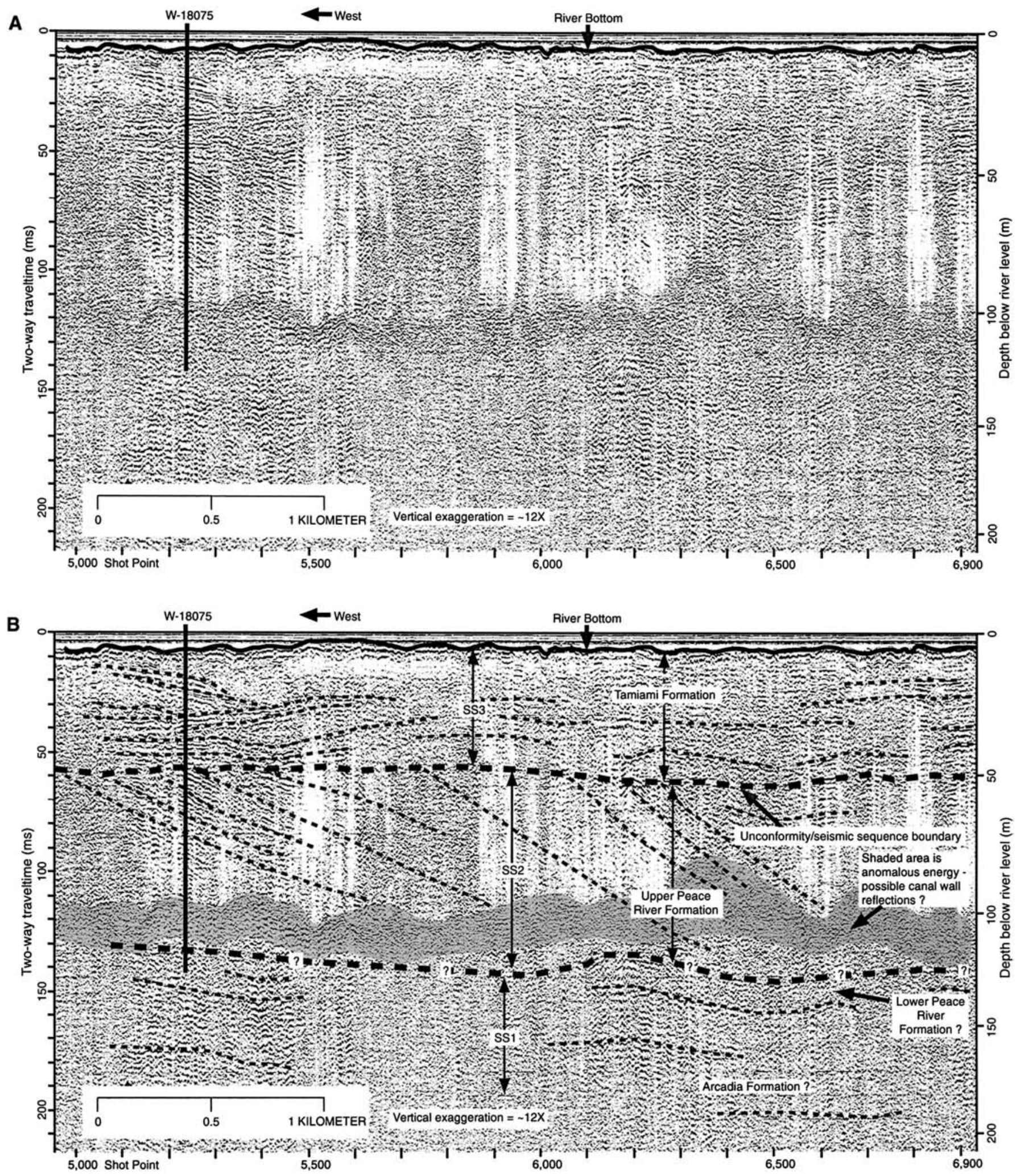

FIG. 4.-A) Uninterpreted reflection-seismic profile along corehole W-18075. B) Interpreted reflection-seismic profile along corehole W-18075. A thick section of oblique progradational reflections are assigned to the upper Peace River Formation with overlying subhorizontal reflectors assigned to the Tamiami Formation. The top of the SS2 is well defined by truncated reflections. 


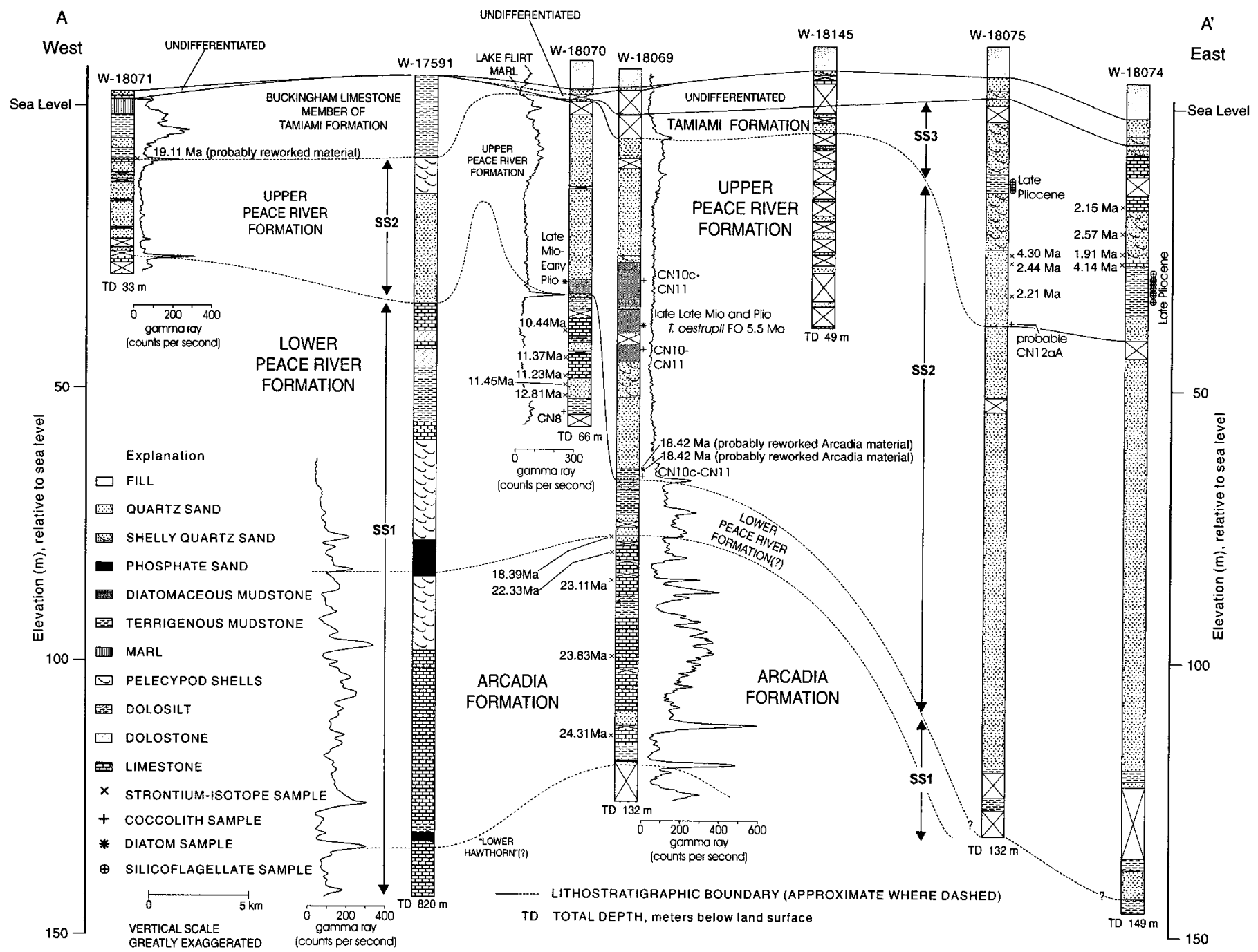

FIg. 5.-Geologic cross section A-A' (Fig. 1B) showing new coreholes and one pre-study well drilled with conventional roller-bit (W-17591) used in calibration of seismic data collected in the Caloosahatchee River. Chronologic results of strontium-isotope chemostratigraphy and micropaleontology are shown. FO $=$ first occurrence. Cunningham et al. (2001b) interpreted the top of the upper contact of the lower Peace River Formation somewhat higher in elevation than that shown here in the W-18075 core.

indicates a range in age between 24.31 and 18.39 Ma for the Arcadia Formation (Figs. 2, 5; Table 1), which is consistent with age determinations by Missimer (1997) and Guertin et al. (2000). Chronostratigraphic results for the lower Peace River Formation indicate an age range between 12.81 and 8.6 Ma (Figs. 2, 5), which is somewhat wider than that $(\sim 11$ to $\sim$ $8.5 \mathrm{Ma}$ ) reported by Missimer (1999). Coccoliths from the lower Peace River Formation in the W-18070 core are assigned to Zone CN8 (Figs. 5, 7; Table 2), suggesting an age of 9.4-8.6 Ma or early Late Miocene, whereas strontium-isotope chemostratigraphic data from the same core produced an age range between 12.81 and 10.44 Ma (Figs. 2, 5; Table 1).

\section{Seismic Sequence 2 (SS2)}

Seismic Data.-Most seismic reflections within SS2 downlap onto the SS1-SS2 seismic unconformity and are truncated at their upper surface (Figs. 1, 3, 4). In the area near coreholes W-18069 and W-18070, SS2 is assigned to the upper Peace River Formation and has reflections that have either a sigmoidal or an oblique progradational configuration (Fig. 3). Where visible, the upper parts of the oblique progradational reflections are terminated by an irregular subhorizontal reflection that represents the dredged floor of the Caloosahatchee River (Fig. 3). SS2 seismic reflections near the W-18075 corehole are discontinuous, oblique, progradational reflectors that are truncated updip by what is interpreted to be a prominent seismic-sequence boundary that separates SS2 and SS3 (Fig. 4).

Core Data.-Cores that penetrated SS2 contain quartz sand, minor terrigenous mudstone, and diatomaceous mudstone. Quartz sands are typically very fine to fine grained and mottled by burrowing (Fig. 6B). The terrigenous mudstone occurs as lamina approximately $1 \mathrm{~mm}$ to $2 \mathrm{~cm}$ thick that make up about 1 percent of the total thickness of SS2 (Fig. 6C). Diatomaceous mudstone constitutes approximately 15 percent of SS2 in the W18069 core with discrete units about $15 \mathrm{~m}$ thick; less than 1 percent of SS2 contains diatomaceous mudstone in the W-18070 core and is absent in the other four cores (W-18071, W-18074, W-18075, and W-18145). The basal part of SS2 is a poorly sorted conglomerate with quartz and phosphorite pebbles as much as $1 \mathrm{~cm}$ in diameter (Fig. 6D). These sediments overlie what is interpreted as an erosional unconformity with $3 \mathrm{~cm}$ of microtopographic relief in the W-18070 core (Fig. 6A).

Biostratigraphic data from the W-18069 and W-18070 cores suggest that SS2 is Early Pliocene in age, with coccoliths that are characteristic of Zones 

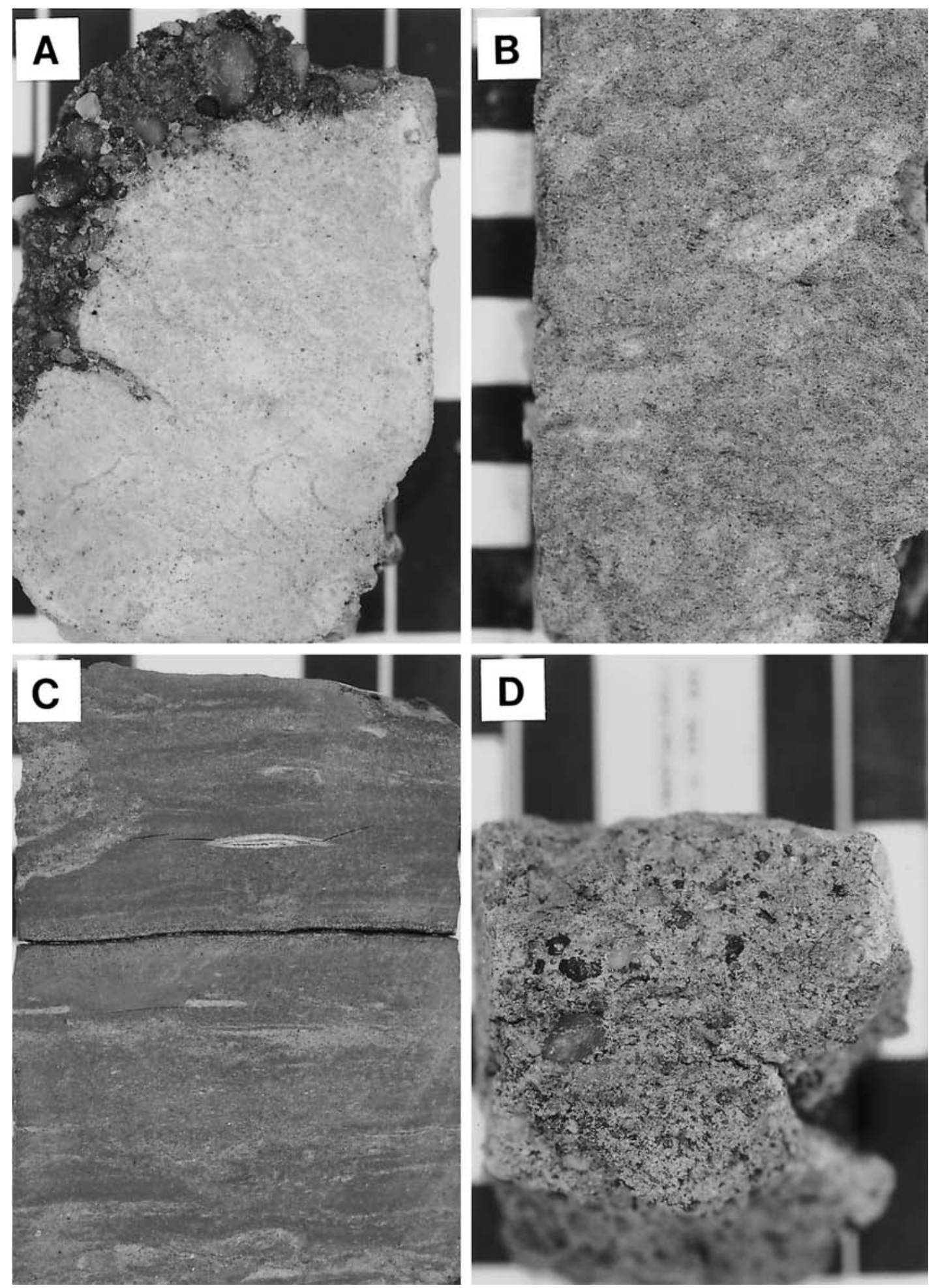

FIG. 6.-Core slabs illustrating depositional aspects of Late Miocene carbonates and Pliocene siliciclastics contained in seismic sequences S1 and S2. A) Sequence boundary at contact between SS1 and SS2 or the lower and upper Peace River Formation, corehole W-18070, $39.1 \mathrm{~m}$. The lithology below the contact is dolosilt, and quartz sand and conglomerate above. Length of photo represents approximately $7 \mathrm{~cm}$. B) Burrow-mottled quartz sand from SS2 or the upper Peace River Formation, corehole W-18070, $11.4 \mathrm{~m}$. Length of photo represents approximately $7.5 \mathrm{~cm}$. C) Terrigenous mudstone with small burrows and discontinuous laminations of very fine quartz sand and silt from SS2 or the upper Peace River Formation, corehole W-18070, $37.3 \mathrm{~m}$. Length of photo represents approximately $7 \mathrm{~cm}$. D) Quartz-pebble conglomerate with a quartz sand matrix from SS2 or the base of the upper Peace River Formation, corehole W-18069, 68.6 m. Length of photo represents approximately $7 \mathrm{~cm}$. 
TABLE 1.-Strontium-isotope chemostratigraphic data and ages from pelecypods collected from coreholes W-18069, W-18070, W-18071, W-18074, and W-18075.

\begin{tabular}{lcllll}
\hline \hline $\begin{array}{c}\text { Local well } \\
\text { identifier }\end{array}$ & $\begin{array}{c}\text { Depth* } \\
(\mathrm{m})\end{array}$ & $\begin{array}{c}\text { Stratigraphic } \\
\text { position }\end{array}$ & ${ }^{87} \mathrm{Sr} /{ }^{86} \mathrm{Sr}$ & Mineralogy $\dagger$ & Age \\
\hline W-18071 & 11.4 & Tamiami & 0.708512 & LMC & $19.11^{* *}$ \\
W-18074 & 20.5 & Tamiami & 0.709081 & Aragonite & 2.15 \\
W-18074 & 25.2 & Tamiami & 0.709069 & Aragonite & 2.57 \\
W-18074 & 28.7 & Tamiami & 0.709088 & Aragonite & 1.91 \\
W-18074 & 30.3 & Tamiami & 0.709053 & Aragonite & 4.14 \\
W-18075 & 35.1 & Tamiami & 0.709051 & LMC & 4.30 \\
W-18075 & 36.2 & Tamiami & 0.709072 & LMC & 2.44 \\
W-18075 & 41.8 & Tamiami & 0.709079 & LMC & 2.21 \\
W-18069 & 66.3 & Upper Peace River & 0.708561 & LMC & $18.42^{* *}$ \\
W-18069 & 66.4 & Upper Peace River & 0.708561 & LMC & $18.42^{* *}$ \\
W-18070 & 45.0 & Lower Peace River & 0.708877 & LMC & 10.44 \\
W-18070 & 49.6 & Lower Peace River & 0.708849 & LMC & 11.37 \\
W-18070 & 50.7 & Lower Peace River & 0.708853 & LMC & 11.23 \\
W-18070 & 52.7 & Lower Peace River & 0.708847 & LMC & 11.45 \\
W-18070 & 55.9 & Lower Peace River & 0.708821 & LMC & 12.81 \\
W-18069 & 77.9 & Arcadia & 0.708563 & LMC & 18.39 \\
W-18069 & 80.8 & Arcadia & 0.708333 & LMC & 22.33 \\
W-18069 & 85.1 & Arcadia & 0.708303 & LMC & 23.11 \\
W-18069 & 98.1 & Arcadia & 0.708267 & LMC & 23.83 \\
W-18069 & 111.1 & Arcadia & 0.708238 & LMC & 24.31 \\
\hline
\end{tabular}

* Depth reported below ground level.

Mineralogy determined from X-ray diffractometer records. LMC is low-magnesium calcite.

* Probable reworked material from the Arcadia Formation.

CN10c-11 and diatoms that indicate an age of less than $5.5 \mathrm{Ma}$ (Figs. 5, 7; Tables 2, 3). However, the siliciclastics of the middle and eastern part of SS2 may correlate to siliciclastics of the Peace River Formation that Cunningham et al. (2001a) argue could be as old as $11 \mathrm{Ma}$ on the basis of age-constrained coreholes to the south (Edwards et al. 1998; Weedman et al. 1999). Because the coccoliths suggest the youngest age of SS1 in the $\mathrm{W}-18070$ core is $8.6 \mathrm{Ma}$, corresponding to the upper boundary of CN8 (Figs. 5, 7; Table 2), and coccoliths indicate an age only as old as $\mathrm{CN10c}$ for SS2 in the W-18069 core (Fig. 5; Table 2), we suggest that the middle and eastern part of the SS2 is Late Miocene(?) to early Early Pliocene (Fig. 1C). As a result, the seismic-sequence boundary separating SS1 and SS2 could represent a hiatus of up to approximately 3.6 Myr spanning the time between 5.04 and $8.60 \mathrm{Ma}$ (Figs. 2, 7). Benthic foraminifers collected from cores that penetrated SS2 are consistent with a shallowing-upward from outer shelf (maximum $200 \mathrm{~m}$ depth) to inner shelf (maximum $100 \mathrm{~m}$ depth) and perhaps lagoon environments (Tables 4, 5). This is shown best in the W-18069 core, where an upward change in the composition of the foraminiferal assemblage, and an upsection increase in numbers and diversity indicate these shallowing-upward conditions (Tables 4, 5).

GPR Data.-The GPR survey at the Indian Mound site (Fig. 1B) images near-surface quartz sands, possibly quartz sand of SS3 and the upper part of SS2 (Fig. 8). Radar reflections assigned to SS2 have a parallel, oblique progradational configuration (Fig. 8). The uppermost inclined radar reflections assigned to SS2 form a toplapping or erosional discordance with overlying horizontal parallel radar reflections tentatively assigned to SS3 (Fig. 8). Verification of assignment of the inclined reflections to SS2 is based on correlation of the GPR survey to the Caloosahatchee River seismic survey and nearby lithologic logs obtained from test wells W-12844 and W-16944 (Fig. 1B). The apparent angle on the south-dipping seismic reflections is about $7^{\circ}$. The parallel, oblique progradational pattern of radar reflections (Fig. 8) may be images of the tops of westward- and eastwardaccreting clinoforms that dip (apparent) as much as $5^{\circ}$. The GPR data helps to fill in the seismic data gap present between the ground level and the Caloosahatchee River channel bottom, which has an approximate $10 \mathrm{~m}$ depth below the land surface.

A nearby quarry provides some information on the textures of the silciclastics shown in the radar profile displayed in Figure 8. Abundant discoid quartz pebbles were observed in spoil banks surrounding a sand pit located near the Indian Mound GPR site (Fig. 1B). Quarry operators indicate that

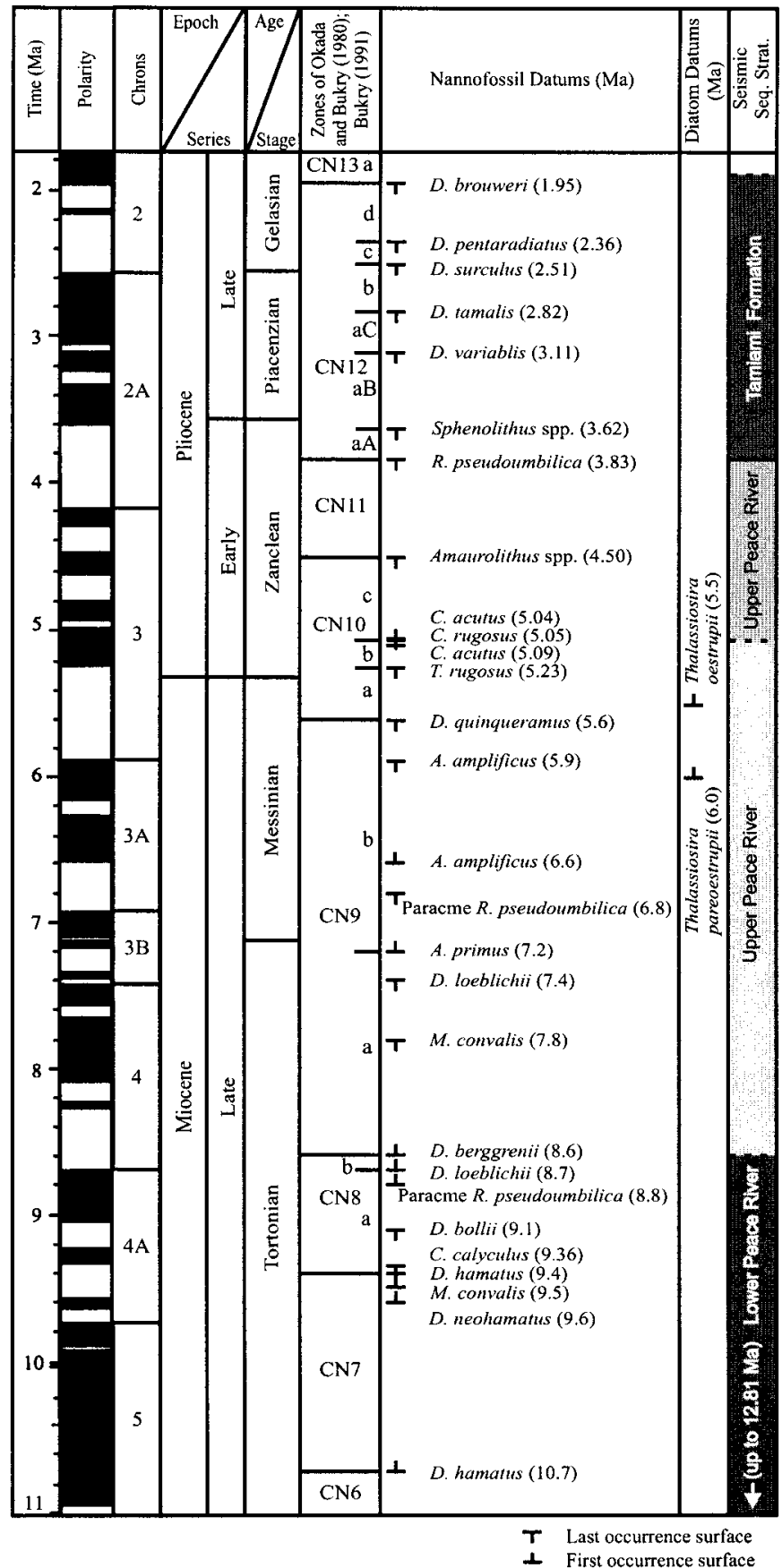

FIG. 7.-Correlation of the chronostratigraphy of part of the Late Tertiary geomagnetic polarity time scale (Berggren et al. 1995) used in this study. Coccolith zonation is from Ocean Drilling Project Leg 171B at the Blake Nose east of the Florida Peninsula (Shipboard Scientific Party 1998) with normalized additions of subzones CN12aA, aB, and aC from Bukry (1991) and diatom datums from offshore California (Barron 1992)

the pebbles have been excavated from strata at a depth equivalent to the dipping reflections shown in Figure 8.

\section{Seismic Sequence 3 (SS3)}

Seismic Data.-SS3 is characterized by discontinuous parallel and subparallel reflections (Fig. 4). Basal seismic reflections of SS3 drape over paleotopography that is present along the boundary between SS2 and SS3 
TABLE 2.-Occurrence of stratigraphically important coccolith taxa in coreholes W-18069, W-18070, and W-18075.

\begin{tabular}{lcll}
\hline \hline $\begin{array}{c}\text { Well } \\
\text { identification }\end{array}$ & $\begin{array}{c}\text { Sample } \\
\text { depth* }(\mathrm{m})\end{array}$ & $\begin{array}{c}\text { Stratigraphic } \\
\text { position }\end{array}$ & $\begin{array}{c}\text { Nannofossil } \\
\text { Zone }\end{array}$ \\
\hline W-18075 & 46.7 & Tamiami & Probable \\
& & & CN12aA \\
W-18069 & 35.3 & UPR & CN10c-11 \\
W-18069 & 46.9 & UPR & CN10-11 \\
W-18069 & 68.1 & UPR & CN10c-11 \\
W-18070 & 36.9 & UPR & Mio-Plio \\
W-18070 & 58.7 & LPR & CN8 \\
\hline
\end{tabular}

Abbreviations: UPR $=$ upper Peace River Formation, LPR $=$ lower Peace River Formation.

* Depth reported below ground level.

Note: Samples from the following depths* in meters were barren. (1) W-18069, UPR 33.3, 40.9, and 42.8* Note: Samples from the following depths* in meters were barren. (1) W-18069, UPR 33.3, 40.9, and 42.8;
LPR 70.3; Arcadia 89.2. (2) W-18070, LPR 39.6. (3) W-18074, Tamiami 30.5, 31.2, 32.9, 33.4, 34.6, 35.4, LPR 70.3; Arcadia 89.2. (2) W-18070, LPR 39.6. (3) W-18074, Tamiami 30.5, 31.2, 32.9, 33.4, 34.6, 35.4,
36.6, 36.9,38.1, 38.5, and 39.7; UPR 63.6, 76.7, 92.2,97.2, 99.6, 102.9, 107.4, 110.1, 113.2, 116.8, 130.8 , 36.6, 36.9, 38.1, 38.5, and 39.7; UPR 63.6, 76.7, 92.2, 97.2, 99.6, 102.9, 107.4, 110.1, 113.2, 116.8, 130.8,
and 135.7; LPR? 136.9 and 138.1. (4) W-18075, Tamiami 22.2, 22.7, 23.4, and 23.7; UPR 68.9.74.1, 82.3, 86.2.95.0, 95.1, 102.0, 102.3, 105.0, 111.7, 112.0, and 116.4; LPR? 121.3, 121.4, 125.3, and 127.3. (5) W$86.2,95.0,95.1,102.0,102.3,105.0,111.7$
18145 , UPR 17.7, 21.7, 21.8, and 22.0.

(Fig. 4). This discontinuity is defined by truncated reflections at the top of SS2 (Fig. 4).

Core Data.-Vertically mixed quartz sand, limestone, and mudstone representative of SS3 were penetrated in the W-18074 and W-18075 coreholes (Figs. 1, 4, 5). Core descriptions (Cunningham et al. 2001b) representative of SS3 match the lithology of the Tamiami Formation as described by Missimer (1992), and thus the seismic reflections of SS3 are assigned to the Tamiami Formation (Figs. 1,2). The truncation surface at the top of SS2 (Fig. 4) is interpreted to correlate to an unconformity that is present at the top of the upper Peace River Formation (Missimer 1999). Missimer (1999) used magnetostratigraphy, calcareous nannofossils, and strontium-isotope ages to demonstrate that the unconformity separating the Tamiami and upper Peace River formations in southwestern Florida represents a 0.2 Myr hiatus.
The presence of rare Discoaster surculus and Sphenolithus sp. but without Reticulofenestra pseudoumbilica coccoliths, collected from the basal 1 $\mathrm{cm}$ of SS3 in the W-18075 core, indicates a precise assignment to Subzone CN12aA or late Early Pliocene (Figs. 5, 7; Table 2). Core samples obtained from the lower (W-18074 corehole) and middle parts (W-18075 corehole) of SS3 contain mudstones with the silicoflagellates Dictyocha ornata africana, D. ornata ornata, and D. tamarae (Fig. 5; Table 6). These silicoflagellate taxa indicate that the middle and upper parts of SS3 are Late Pliocene. Strontium-isotope chemostratigraphy of the middle of SS3 in the W-18074 and W-18075 cores produced a range in age from 4.30 to 1.91 Ma (Fig. 5; Table 1) or late Early to Late Pliocene.

\section{DISCUSSION}

\section{Local and Regional Depositional Events}

Three seismic sequences (SS1-SS3) imaged beneath the Caloosahatchee River and data from six new coreholes document a Middle to Late Cenozoic (1) cessation of carbonate-ramp sedimentation on the southeastern part of the Florida Platform, (2) subaerial erosion of the ramp, (3) flooding of the exposure surface by an approximate $100 \mathrm{~m}$ rise in relative sea level, (4) filling of resulting accommodation by siliciclastics, and (5) return to carbonate-platform growth. SS1 delineates an aggradational, mixed carbonate-siliciclastic ramp of Late Oligocene to early Late Miocene age comprising the Arcadia Formation and lower Peace River Formation (Figs. 2, 9A). The Arcadia Formation was deposited during the Late Oligocene to the Middle Miocene in south Florida (Guertin et al. 2000), and its upper surface is bounded by a regional unconformity (Fig. 10A). We speculate that this unconformity is equivalent to the "Middle Miocene unconformity" Mullins et al. (1988) observed on the margin of the west Florida carbonate platform. Development of this unconformity has been attributed to

TABLE 3.-Occurrence of stratigraphically important diatom taxa in coreholes W-18069, W-18070, and W-18074.

\begin{tabular}{|c|c|c|c|c|c|c|c|c|c|c|c|c|c|c|c|c|c|c|}
\hline $\begin{array}{l}\text { Well } \\
\text { identification }\end{array}$ & $\begin{array}{l}\text { Sample } \\
\text { depth* } \\
\text { (m) }\end{array}$ & $\begin{array}{l}\text { Strati- } \\
\text { graphic } \\
\text { unit }\end{array}$ & $\begin{array}{l}\text { Sub } \\
\text { Epoch }\end{array}$ & $\begin{array}{l}\text { Estimated } \\
\text { age } \\
\text { (Ma) }\end{array}$ & 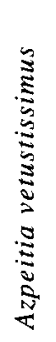 & 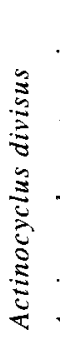 & 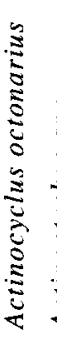 & 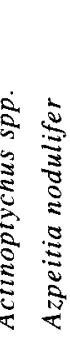 & 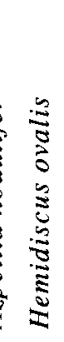 & 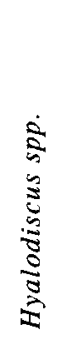 & 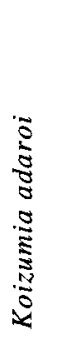 & 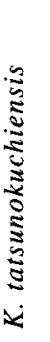 & 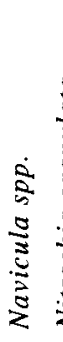 & 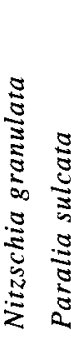 & & & $\frac{3}{2}$ & \\
\hline W-18074 & 31.2 & Tamiami & $\begin{array}{l}\text { Late Miocene to } \\
\text { Recent }\end{array}$ & $<11.2$ & & & & & & $\mathrm{X}$ & & & & & $\bar{x}$ & & & \\
\hline W-18074 & 32.9 & Tamiami & $\begin{array}{l}\text { Late-Late } \\
\text { Miocene to } \\
\text { Pliocene }\end{array}$ & $<5.5$ & & & & & $x$ & & & & & $\bar{x}$ & & & & \\
\hline W-18074 & 36.6 & Tamiami & $?$ & $?$ & & $|\mathrm{x}|$ & \begin{tabular}{l|l}
$x$ \\
\end{tabular} & \begin{tabular}{l|l}
$\mathrm{X}$ & $\mathrm{X}$ \\
\end{tabular} & $\mathrm{s}$ & \begin{tabular}{|l|}
$\mathrm{X}$ \\
\end{tabular} & & & \begin{tabular}{|l|}
$\mathrm{x}$ \\
\end{tabular} & & \begin{tabular}{l|l}
$x$ & $x$ \\
\end{tabular} & $\mathrm{X}$ & & \\
\hline W-18069 & 33.3 & UPR & $\begin{array}{l}\text { Late-Late to } \\
\text { Early Pliocene }\end{array}$ & $<5.5$ & & & & & $\bar{X}$ & & & $\mathrm{X}$ & & & & 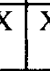 & \begin{tabular}{l|l}
$\mathrm{x}$ & \\
\end{tabular} & \\
\hline W-18069 & 42.8 & UPR & $\begin{array}{l}\text { Late-Late to } \\
\text { Early Pliocene }\end{array}$ & $<5.5$ & & & & & $\mathrm{X}$ & & & & & & $\bar{x}$ & $\bar{x}$ & $\overline{2}$ & $\mathrm{X}$ \\
\hline W-18070 & 36.9 & UPR & $\begin{array}{l}\text { Late-Late } \\
\text { Miocene } \\
\text { to Early Pliocene }\end{array}$ & $<6.0$ & $\mathrm{X}$ & & & & & & $\mathrm{x}$ & $\mathrm{x}$ & & & & \begin{tabular}{l|l}
$\mathrm{X}$ & $\overline{1}$
\end{tabular} & $\bar{X}$ & \\
\hline
\end{tabular}

Abbreviations: $\mathrm{X}=$ present, UPR=upper Peace River Formation, LPR=lower Peace River Formation.

*Depth reported below ground level.

Note: Samples from the following depths* in meters were barren. (1) W-18069, UPR 68.1; LPR 70.3; Arcadia 89.2 and 113.7. (2)

W-18070, LPR 39.6 and 58.7. (3) W-18074, Tamiami 39.7; UPR 63.6, 76.7, 92.2, 97.2, 99.6, 102.9, 107.4, 110.1, 113.2, 116.8, 130.8,

135.7; LPR? 136.9 and 138.1. (4) W-18075, UPR 68.9, 74.1, 82.3, 86.2, 95.0, 95.1, 102.0, 102.3, 105.0, 111.7, 112.0, and 116.4; LPR?

$121.3,121.4,125.3$ and 127.3. (5) W-18145, UPR 17.7, 21.7, 21.8, and 22.0. 
TABLE 4.-Benthic foraminiferal genera listed alphabetically and their distribution with depth in coreholes W-18069, W-18070, W-18071, W-18074, and W-18075.

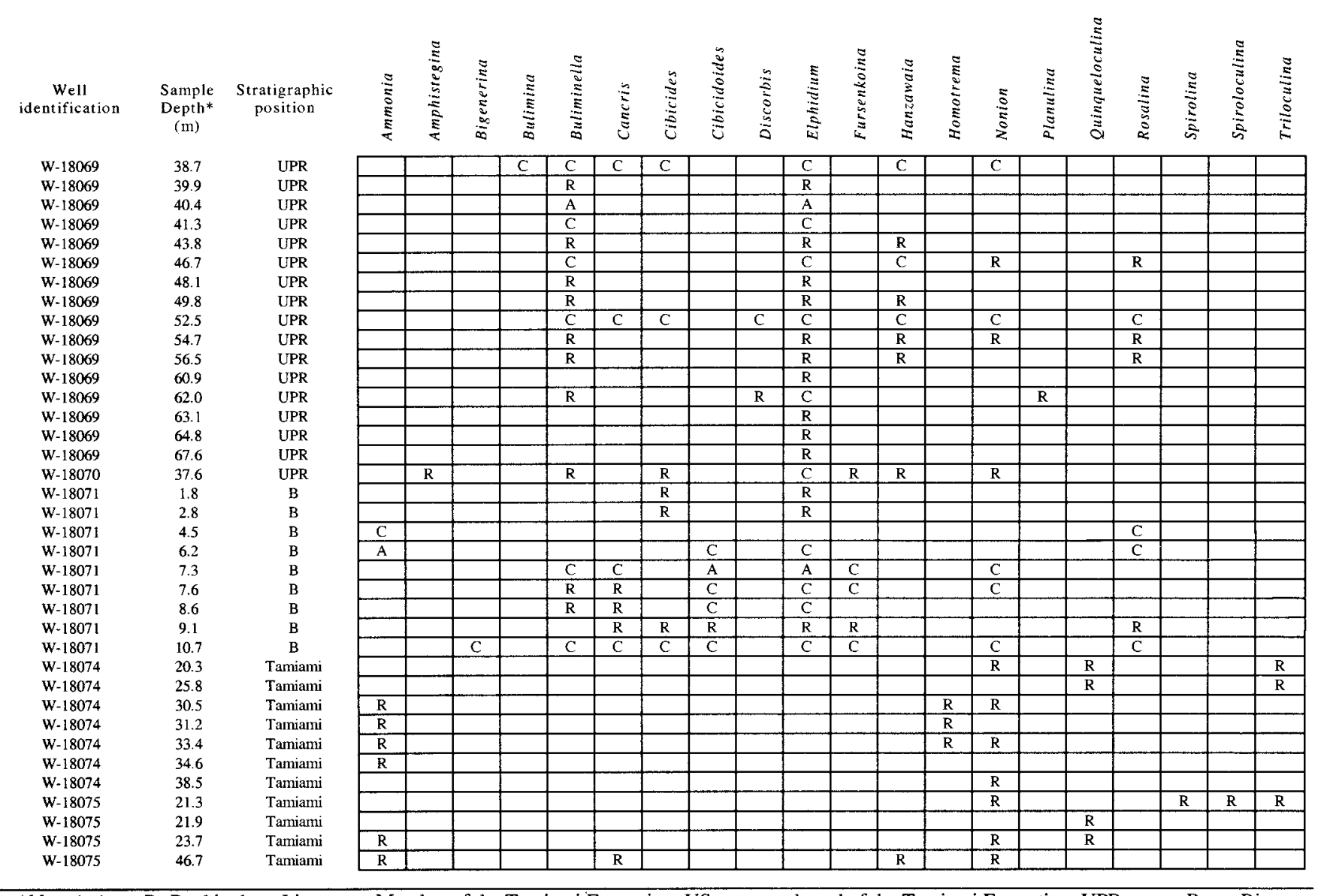

Abbreviations: $\mathrm{B}=$ Buckingham Limestone Member of the Tamiami Formation, US=unnamed sand of the Tamiami Formation, UPR=upper Peace River Formation, $L P R=$ lower Peace River Formation, $A=$ abundant ( $>45$ specimens per sample), $C=$ common $(15-45$ specimens per sample), $R=$ rare $(<15$ specimens per sample).

*Depth reported below ground level.

Note: Samples from the following depths* in meters were barren. (1) W-18069, US 13.7; UPR 16.6, 18.0, 20.7, 23.2, 24.9, 27.2, 29.4, 30.6, 31.6, 34.8, 36.6, and 68.2. (2) W-18070, UPR 9.8, 13.0, 16.6, 19.8, 22.7, 25.4, 28.3, 33.3, 36.9, 38.5, and 39.0. (3) W-18071, B 10.3 and 11.1; UPR 12.3, 14.4, 16.8, 18.5, 20.6, 21.9, 22.6, 23.6, 24.1, and 26.4. (4) W-18074, undifferentiated 6.3 and 8.7; Tamiami 11.7, 32.9, 35.4, 36.6, 36.9, 38.1, and 39.7; UPR 47.7, $54.5,63.6,68.2,76.7,77.9,84.7,92.2,97.2,99.6,102.8,107.4,110.1,113.2,116.8,130.8$, and 135.9; LPR? 136.9, and 138.1.

an increase in flow velocity and volume of paleoceanographic currents (Loop Current) flowing across the Florida Platform, which resulted in truncation of seaward-prograding clinoforms at the west Florida margin. Intensification of these currents has been attributed to tectonic restriction of the Isthmus of Panama, climatic change, or both (Mullins et al. 1987). As previously proposed by Guertin et al. (2000), we conclude that this current influenced development of the unconformity bounding the top of the Arcadia Formation in southern peninsular Florida. At the Caloosahatchee River study area, Middle Miocene eustatic highstands (Fig. 2) may have also contributed to shutting down Arcadia Formation carbonate deposition by drowning of the platform top (Schlager 1981).

Deposition of the lower Peace River Formation likely corresponds to the initial aggradation of the "sequence I" carbonate ramp of Mullins et al. (1988) at the west Florida margin. Stratigraphic evidence presented in Guertin et al. (2000) and Cunningham et al. (2001a) indicates that the lower Peace River Formation backsteps northward of the southern limit of the Arcadia Formation at the southern edge of the Florida Platform (Fig. 10B). This backstepping is probably related to recovery of carbonate deposition following Middle Miocene drowning and erosion of the Arcadia Formation ramp. The erosional truncation of reflections at the top of SS1 in the vicinity of the W-18069 and W-18070 coreholes (Fig. 3) is interpreted to be related to subaerial exposure, with collapse of the upper surface of SS1 in the area of the W-18071 corehole (Figs. 1, 9A) probably related to karst development. Thus the relatively steeply sloping plateau-to-valley erosional transition shown in Figure 9A is suggested to be related to subaerial erosion, but, this erosion may have only enhanced a distally steepened break in slope (cf. Read 1985) of the lower Peace River ramp, which shows a maximum apparent dip of $3^{\circ}$ (Figs. 1C, 3, 5, 9A). This major break in slope is shown in Figures 1C, 3, 5, and 9A, where west of the W-18069 corehole there is a high ratio of carbonate rock to mudstone in the lower Peace River Formation of the W-18071, W-17591, and W-18070 coreholes, but at the W-18069 corehole along the ramp break in slope there is a low ratio of carbonate rock to mudstone in the lower Peace River Formation (Fig. 5). The low ratio at the W-18069 core is probably related to the occurrence of the break in slope of the lower Peace River ramp seaward of high-energy, shallow-marine environments. Perhaps the interpreted karst at the top of SS1 is related to the Late Miocene karst surface at the top of "sequence ID" of Mullins et al. (1988) on the west Florida margin. How- 
TABLE 5.-Ecological data for benthic foraminiferal genera identified in coreholes W-18069, W-18070, W-18071, W-18074, and W-18075.

\begin{tabular}{|c|c|c|}
\hline Genus & $\begin{array}{l}\text { Depth* } \\
\text { (m) }\end{array}$ & Environment \\
\hline Ammonia & $0-50$ & Brackish and hypersaline lagoons, inner shelf \\
\hline Amphistegina & $0-130$ & Coral reefs, lagoons \\
\hline Bigenerina & & Shelf \\
\hline Bulimina & & Inner shelf to bathyal \\
\hline Buliminella & & $\begin{array}{l}\text { Mainly shelf, but also lagoons and upper } \\
\text { bathyal }\end{array}$ \\
\hline Cancris & $50-150$ & Inner shelf \\
\hline Cibicides & $0-\geq 2000$ & Lagoons to bathyal \\
\hline Cibicidoides & & Shelf to bathyal \\
\hline Discorbis & $0-50$ & Shelf \\
\hline Elphidium $\dagger$ & $0-50$ & $\begin{array}{l}\text { Brackish to hypersaline marshes, lagoons, in- } \\
\text { ner shelf }\end{array}$ \\
\hline Fursenkoina & $0-1200$ & Lagoons to upper bathyal \\
\hline Hanzawaia & & Inner shelf \\
\hline Homotrema & & Marine, inner shelf \\
\hline Nonion & $0-180$ & Shelf \\
\hline Planulina & & Shelf, bathyal \\
\hline Quinqueloculina & & Hypersaline lagoons, marine shelf \\
\hline Rosalina & $0-100$ & Lagoon, inner shelf \\
\hline Spirolina & $0-60$ & Lagoons and nearshore \\
\hline Spiroloculina & $0-40$ & Lagoons, inner shelf \\
\hline Triloculina & & $\begin{array}{l}\text { Mainly hypersaline lagoons or marine inner } \\
\text { shelf }\end{array}$ \\
\hline
\end{tabular}

$\uparrow$ Poag (1981) states that Elphidium is abundant and widespread in coastal lagoons, bays, and estuaries.

ever, our geochronological data suggests roughly a $2.5 \mathrm{Myr}$ difference in surface ages, whereas the upper surface of "sequence ID" of Mullins et al. (1988) was keyed interpretively into the major eustatic lowstand at the end of TB2.6 eustatic cycle of Haq et al. (1988) and not by precise age dating.

Initial westward and eastward accretion of the siliciclastic clinothems of SS2 over the lower Peace River Formation occurred in the paleo-valley shown in Figure 9A. Deposition is interpreted to have been initiated after a rise in relative sea level of about $100 \mathrm{~m}$ (vertical distance from the toes of larger clinoforms to tops, Figs. 1, 3, 9B) following exposure of the top of SS1. This interpretation is consistent with the vertical succession of benthic foraminifers in the Caloosahatchee cores that indicate shallowing upward of the SS2 siliciclastic clinoforms from outer-shelf to inner-shelf and possibly lagoon environments. The Late Miocene(?) to early Early Pliocene siliciclastics of SS2 (Figs. 1C, 9B) are probably correlative, at least in part, to Peace River siliciclastics (DS2 and possibly DS1 of Cunningham et al. 2001a) that extend over a broad area of south Florida (Fig. 10C; Cunningham et al. 2001a). Deposition of the SS2 siliciclastic clinoforms continued into the Pliocene and spilled onto the paleo-plateau shown in Figure 9A after accommodation was filled to the east (Fig. 9C). These Early Pliocene siliciclastics (Fig. 2) are contemporaneous with a siliciclastic depositional sequence (DS3) mapped on the eastern Florida peninsula by Cunningham et al. (2001a) and the upper Peace River Formation of Missimer (1999) in southwestern Florida, which suggests their rather limited extent depicted in Figure 10D. The backstepping of later SS2 siliciclastic deposition as shown in Figure 10D may be related to highstand sea-level events during the Early Pliocene (Fig. 2) or possibly related to diversion of fluvial drainage in the area of the Gulf Trough.

The SS3 sequence or Tamiami Formation indicates that minor carbonate deposition resumed in southern Florida during the latest Early and Late Pliocene (Fig. 2) with a shift from the progradational SS2 siliciclastic clinoforms to aggradation of the vertically mixed carbonates and siliciclastics of SS3 (Figs. 1C, 9D). The probable CN12aA assignment of the base of SS3 in the W-18075 corehole suggests that the deposition of the mixed carbonates and siliciclastics of SS3 began with the beginning of the TB3.6 eustatic rise (Fig. 2) in sea level of Haq et al. (1988). If this eustatic interpretation is valid, then it is possible that the unconformity bounding the top of SS2 in the area of the W-18075 corehole is related to the eustatic
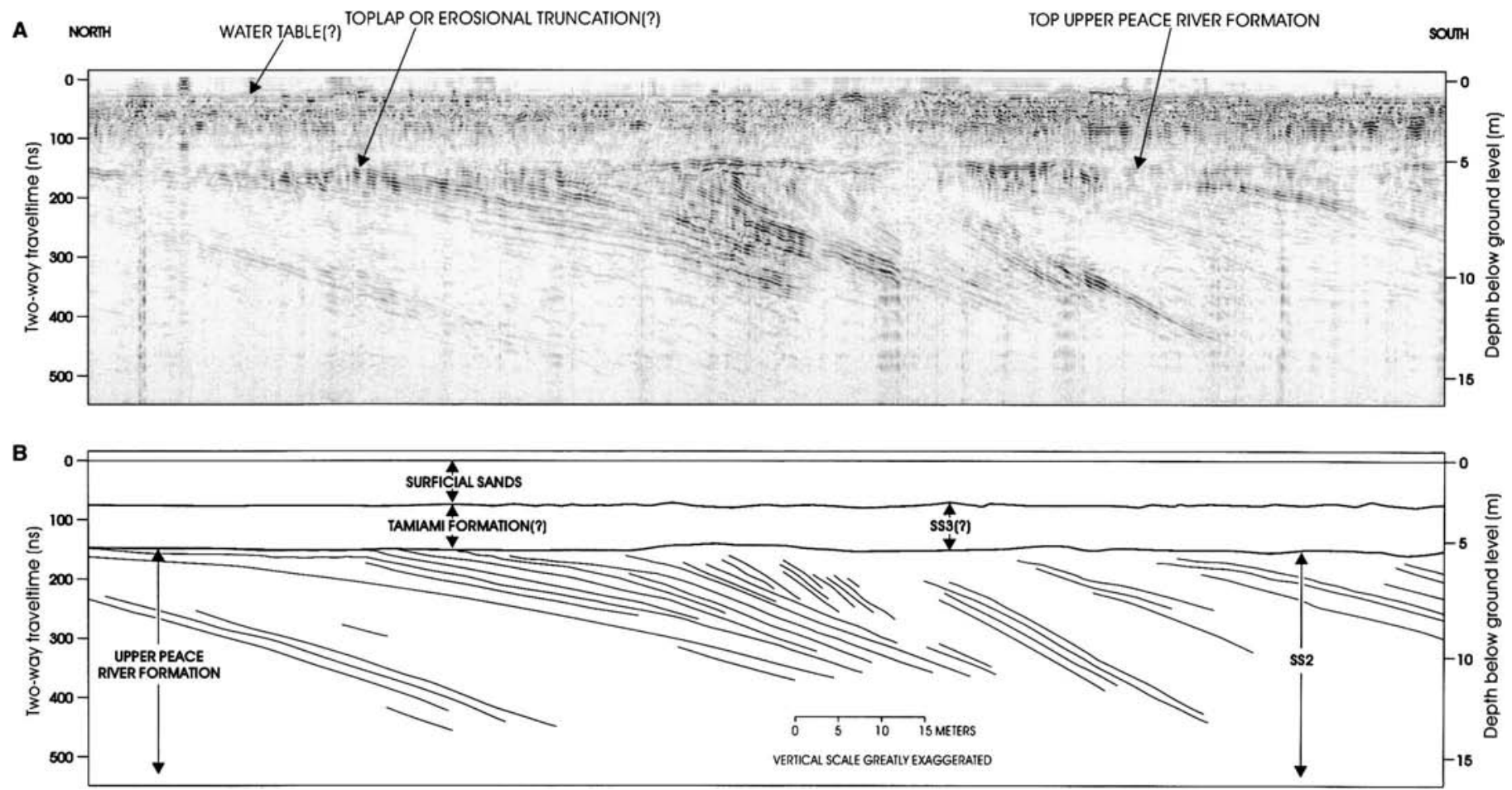

FIG. 8.-A) Ground-penetrating radar profile and B) interpretive line drawing from the Indian Mound site north of the Caloosahatchee River (Fig. 1B). The radar profile is sited along the apparent depositional axis of the SS2 deltaic depositional system. The radar profile shows parallel, oblique southward-prograding reflections. The inclined reflections are interpreted to be images of low-angle, accretionary foreset beds that represent the uppermost part of a southward-prograding delta imaged in Figures 3 and 4. A deep sand pit is located about $150 \mathrm{~m}$ north of the profile. Sediment samples recovered from the pit indicate that the entire profile is imaging quartz sand. 
TABLE 6.-Occurrence of stratigraphically important silicoflagellate taxa in coreholes $\mathrm{W}-18074$ and $\mathrm{W}-18075$.

\begin{tabular}{|c|c|c|c|c|c|c|}
\hline $\begin{array}{c}\text { Well } \\
\text { identification }\end{array}$ & $\begin{array}{l}\text { Sample } \\
\text { depth* } \\
\text { (m) }\end{array}$ & $\begin{array}{l}\text { Strati- } \\
\text { graphic } \\
\text { unit }\end{array}$ & $\begin{array}{l}\text { Sub } \\
\text { Epoch }\end{array}$ & 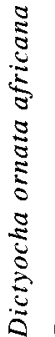 & $\begin{array}{c}0 \\
0 \\
0 \\
0 \\
0 \\
0 \\
0 \\
0 \\
0 \\
0 \\
0 \\
0\end{array}$ & 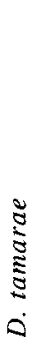 \\
\hline W-18074 & 31.2 & Tamiami & $\begin{array}{c}\text { Late } \\
\text { Pliocene }\end{array}$ & \begin{tabular}{|l|}
$x$ \\
\end{tabular} & $\mathrm{x}$ & $\mathrm{X}$ \\
\hline W-18074 & 32.9 & Tamiami & $\begin{array}{c}\text { Late } \\
\text { Pliocene }\end{array}$ & $\mathrm{X}$ & $\mathrm{X}$ & $\mathrm{X}$ \\
\hline W-1 8074 & 33.4 & Tamiami & $\begin{array}{c}\text { Late } \\
\text { Pliocene }\end{array}$ & $\mathrm{X}$ & $\mathrm{X}$ & $\mathrm{X}$ \\
\hline W-18074 & 34.6 & Tamiami & $\begin{array}{c}\text { Late } \\
\text { Pliocene }\end{array}$ & $\mathrm{X}$ & $\mathrm{X}$ & $\mathrm{X}$ \\
\hline W-18074 & 35.4 & Tamiami & $\begin{array}{c}\text { Late } \\
\text { Pliocene }\end{array}$ & $\mathrm{X}$ & $\mathrm{X}$ & $x$ \\
\hline W-18074 & 36.6 & Tamiami & $\begin{array}{c}\text { Late } \\
\text { Pliocene }\end{array}$ & $\mathrm{X}$ & $\mathrm{X}$ & $x$ \\
\hline W-18074 & 36.9 & Tamiami & $\begin{array}{c}\text { Late } \\
\text { Pliocene }\end{array}$ & \begin{tabular}{|l|}
$\mathrm{X}$ \\
\end{tabular} & $\mathrm{X}$ & $x$ \\
\hline W-18074 & 38.1 & Tamiami & $\begin{array}{c}\text { Late } \\
\text { Pliocene }\end{array}$ & \begin{tabular}{|l|}
$X$ \\
\end{tabular} & $\mathrm{X}$ & $x$ \\
\hline W-18075 & 22.2 & Tamiami & $\begin{array}{c}\text { Late } \\
\text { Pliocene }\end{array}$ & $\mathrm{X}$ & $X$ & \\
\hline W-18075 & 22.7 & Tamiami & $\begin{array}{c}\text { Late } \\
\text { Pliocene }\end{array}$ & $\mathrm{X}$ & & \\
\hline W-18075 & 23.4 & Tamiami & $\begin{array}{c}\text { Late } \\
\text { Pliocene }\end{array}$ & \begin{tabular}{|l|}
$\mathrm{X}$ \\
\end{tabular} & & $\mathrm{X}$ \\
\hline W-1 8075 & 23.7 & Tamiami & $\begin{array}{c}\text { Late } \\
\text { Pliocene }\end{array}$ & \begin{tabular}{|l|}
$\mathrm{X}$ \\
\end{tabular} & & \\
\hline $\begin{array}{l}\text { Abbreviations: } \mathrm{X} \\
\text { LPR }=\text { lower Pea } \\
\text { *Depth reported } \\
\text { Note: Samples fr } \\
\text { barren. (1) W-18 } \\
97.2,99.6,102.9 \\
\text { LPR? } 136.9 \text { and } \\
86.2,95.0,95.1 \text {, } \\
\text { LPR? } 121.3,121 \\
21.7,21.8 \text {, and } 2\end{array}$ & $\begin{array}{l}=\text { present } \\
\text { ce River } F \\
\text { oelow grou } \\
\text { om the fol } \\
074 \text {, Tami } \\
107.4,11 \\
138.1 .(2) \\
102.0,102 \\
4,125.3, \\
.0 .\end{array}$ & $\begin{array}{l}\text { UPR }=\text { upp } \\
\text { rmation. } \\
\text { ad level. } \\
\text { wing depth } \\
\text { ni } 39.7 ; \text { UF } \\
.1,113.2,1 \\
\text {-18075, U } \\
3,105.0,11 \\
\text { d } 127.3 . \text { (3 }\end{array}$ & $\begin{array}{l}\text { S* in meter } \\
R 63.6,76 \\
16.8,130.8 \\
\text { PR } 68.9,74 \\
1.7,112.0, \\
W-18145\end{array}$ & $\begin{array}{l}\text { rs } \\
6.7,9 \\
8,13 \\
4.1,8 \\
\text { and } \\
5 \text {, UP }\end{array}$ & $\begin{array}{l}\text { ere } \\
2.2, \\
8.7 \\
82.3 \\
116\end{array}$ & $\begin{array}{l}.4 \\
7.7\end{array}$ \\
\hline
\end{tabular}

fall in sea level at the end of TB3.5 eustatic cycle (Fig. 2). Deposition of SS3 was widespread throughout southern Florida (Fig. 10E) and included the deposition of a carbonate ramp that is depicted at its base in Figure 10E (see Cunningham et al. 2001a). The siliciclastics of SS3 are present in the northern Florida Keys and may extend out to or near the present Florida reef tract and shelf margin (Fig. 10E).

The siliciclastic " platform"' constructed in southern peninsular Florida by the end of the Pliocene provided a relatively shallow, marine substrate for carbonate growth, and the relatively warm climatic conditions of the Early Pleistocene (Willard et al. 1993) coupled with higher frequency sealevel changes (Fig. 2) of the Pleistocene likely contributed to the development of the well-known Quaternary carbonates and rimmed shelf margin (Read 1985) of the Florida Keys (Fig. 10F; Enos and Perkins 1977). Had deposition of SS2 siliciclastics and SS3 mixed siliciclastics and carbonates not filled accommodation on the southeast Florida Platform during the Late Miocene and Pliocene, as shown in Figure 10B, it is likely that the return to shallow-marine carbonate deposition as a reef-rimmed shelf would not have occurred.

\section{Evidence for a Siliciclastic Conveyor}

The sand-rich clinoforms of the SS2 sequence are more than $100 \mathrm{~m}$ thick and dip in a westward and eastward direction (with apparent dips of up to $7^{\circ}$ ) more or less symmetrically from an area somewhat east of the W-18145 corehole (Figs. 1C, 3, 4). These clinoforms of SS2 extend for approximately $35 \mathrm{~km}$ along the eastern half of the Caloosahatchee River (Fig. 1). Even though the Caloosahatchee River seismic data are a single two-dimensional profile, the combined apparent dips of clinoforms in the seismicreflection profiles (Figs. 1C, 3, 4) and GPR profile (Fig. 8) indicate southward progradation of the SS2 clinoformal complex. However, other possible, but less likely, progradational configurations cannot be ruled out until a three-dimensional grid of seismic profiles is collected.

The SS2 clinoforms are interpreted to represent a deltaic depositional system, at least $100 \mathrm{~m}$ thick, which has reflection geometries similar to those of deltas interpreted from seismic profiles in the Fort Myers area (Fig. 1; Missimer 1999; Evans and Hine 1991) and elsewhere in southwestern Florida (Evans and Hine 1991). Mudstones at the base of the W18069, W-18070, W-18074, and W-18075 cores are interpreted as representative of prodelta environments associated with initiation of each shallowing-upward stratal package within the SS2 sequence. This interpretation is consistent with benthic foraminiferal data that suggests an outer-shelf environment in the lower parts of the SS2 clinoforms. For perspective, the width and thickness of this set of clinoforms is comparable to the Holocene Balize and Plaquemine deltaic lobes of the Mississippi River (Kolb and Van Lopik 1966). However, we do not propose that the huge height and width of the aggrading complex of clinoforms are evidence of a fluvial system the size of the Mississippi delta, but the large size of the clinoform complex does suggest a depositional system that is unprecedented in scale relative to any fluvial or coastal marine depositional system operating today in the eastern Gulf of Mexico. The deltaic interpretation for the SS2 clinoforms is consistent with Bishop's (1956) identification of deltaic foreset beds in sediments of the central peninsular Florida Lake Wales Ridge in Polk County about $120 \mathrm{~km}$ to the north. Also, Klein et al. (1964) suggest that clastic sediment with quartz pebbles in Hendry County represents the bottomset beds of a deltaic finger that progressed southward across Highlands County during the Late Miocene (cf. Fig. 10C). At our Indian Mound GPR site (Fig. 1B), the probable presence of discoid pebbles within the southward-dipping beds of SS2 (Fig. 8) is consistent with deposition in beach environments (Dobkins and Folk 1970), which are a common deltaic environment.

As an alternative, Winker and Howard's (1977) suggestion that the Miocene and Pliocene clastics of the central Florida peninsula were introduced by longshore transport must be considered. However, their data are based on the Pliocene rather than on the Miocene, and do not explain the Pliocene delta interpreted by Missimer (1999) near Fort Myers. Also, as an alternative to riverine transport, we must consider the possibility of a giant prograding spit forming the clinothems of the Caloosahatchee River seismic profiles, as suggested by Warzeski et al. (1996). But the spit hypothesis of Warzeski et al. (1996) was developed from seismic profiles seaward of the Florida Keys and is not consistent with the deltaic foreset beds interpreted by Bishop (1956) some $120 \mathrm{~km}$ north of the Caloosahatchee River study area.

Cunningham et al. (1998) postulated the presence of a corridor of maximum current strength that focused southward transport of Late Tertiary siliciclastics in the area where the Caloosahatchee River delta is imaged in seismic profiles. This interpretation was based on mapping of an inferred siliciclastic transport pathway of Late Tertiary siliciclastics by Warzeski et al. (1996) and mapping of a coincidental sinuous north-south oriented paleo-low spanning the top of the lower Peace River Formation and the un- 

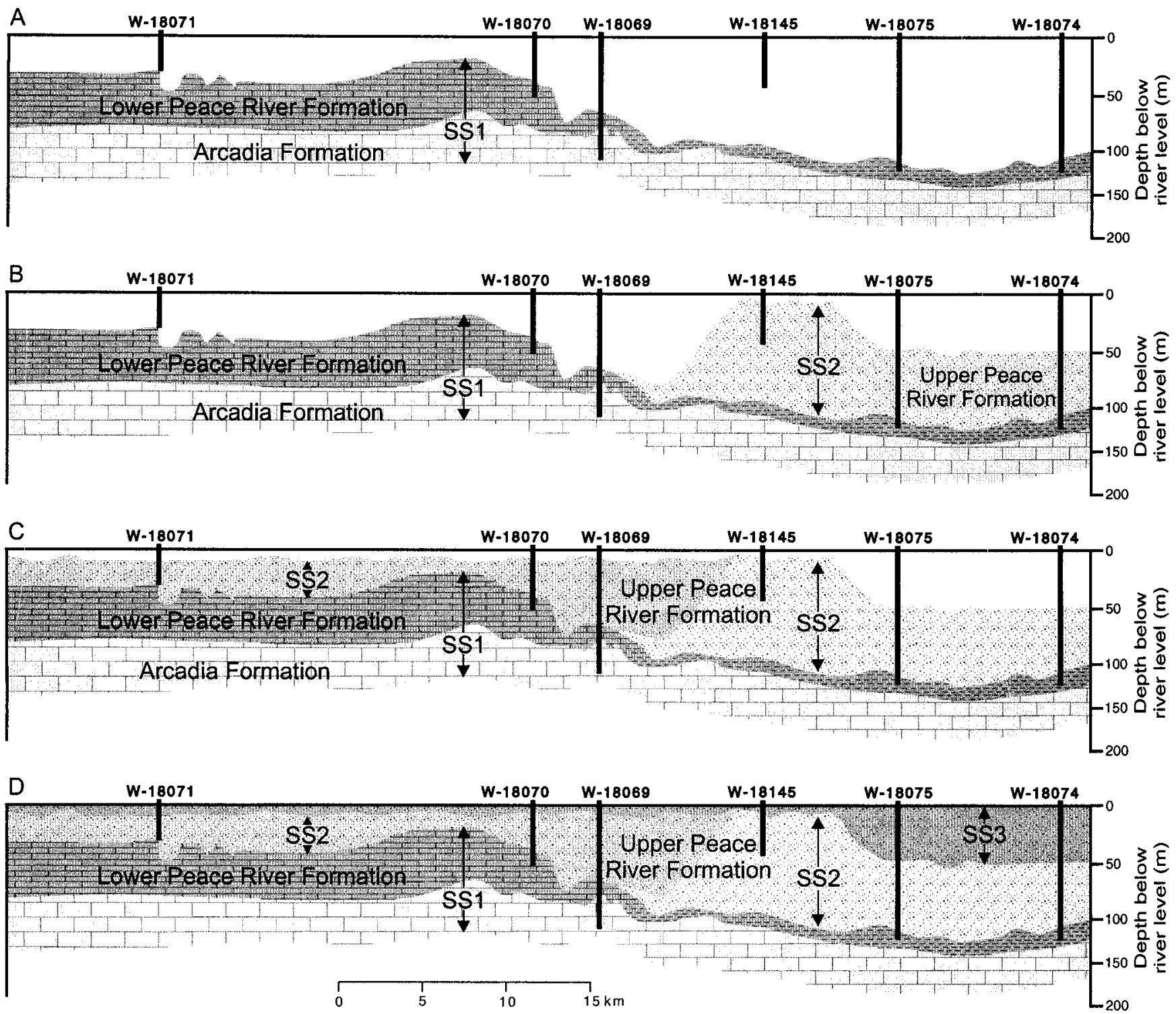

FIg. 9.-Reconstruction of the depositional history of the Caloosahatchee River study area. A) SS1, consisting of the Arcadia and lower Peace River Formations. B) Late Miocene(?) to Early Pliocene portion of SS2 or upper Peace River Formation. C) Early Pliocene portion of SS2 or upper Peace River Formation. D) Latest Early Pliocene to Late Pliocene portion of SS3.

conformity at the top of the Arcadia Formation. If the deltaic interpretation of the Caloosahatchee River seismic data is correct, the Late MioceneEarly Pliocene siliciclastics beneath the middle and northern Florida Keys were probably transported about $200 \mathrm{~km}$ southward in association with Late Neogene fluvial-deltaic progradation (Figs. 1A, 10C). Correlation of the early Late(?) Miocene to early Early Pliocene succession of SS2 clinoforms (Fig. 1C, 2, 9B) to regional stratigraphic mapping by Cunningham et al. (2001a) strengthens this interpretation. We speculate that the siliciclastics were transported southward along the lowest part of the paleo-valley shown in Figure 9A, which may be linked to the paleo-low mapped by Cunningham et al. (1998). Antecedent relief, present on the upper sequence boundary at the top of SS1, funneled the inferred delta axis southward along the middle of the Florida Platform (Figs. 1A, 10C).

\section{Siliciclastic Influence on Development of Carbonate Florida Platform}

Key controls on development of carbonate platforms are plate motion, subsidence, sea-level change, climate, and oceanographic factors. However, numerous authors have also shown that the interplay of siliciclastic and carbonate deposition can be critical in the initiation and expansion of ancient carbonate platforms (e.g., Choi and Ginsburg 1982; Choi and Holmes 1982; Davies et al. 1989; Meyer 1989; Sonnenfeld and Cross 1993; Ferro et al. 1999).

Although the Florida Platform has maintained carbonate sedimentation throughout the Late Mesozoic to the Quaternary, its Late Miocene to Quaternary history in the southeastern part contains an important record that demonstrates how siliciclastic progradation can be essential to renewal of carbonate-platform growth following termination of carbonate production. In this case, carbonate growth ended in the Miocene. Our model of fluvialdeltaic siliciclastic progradation from the area of the Caloosahatchee River to the present-day shelf edge of the Florida Keys is reinforced by marineseismic profiles from the Keys that can be interpreted as prograding siliciclastic deltaic wedges (Warzeski et al. 1996). This example from the southeastern portion of the Florida Platform shows the importance of siliciclastic filling of accommodation as a means of providing a substratum 


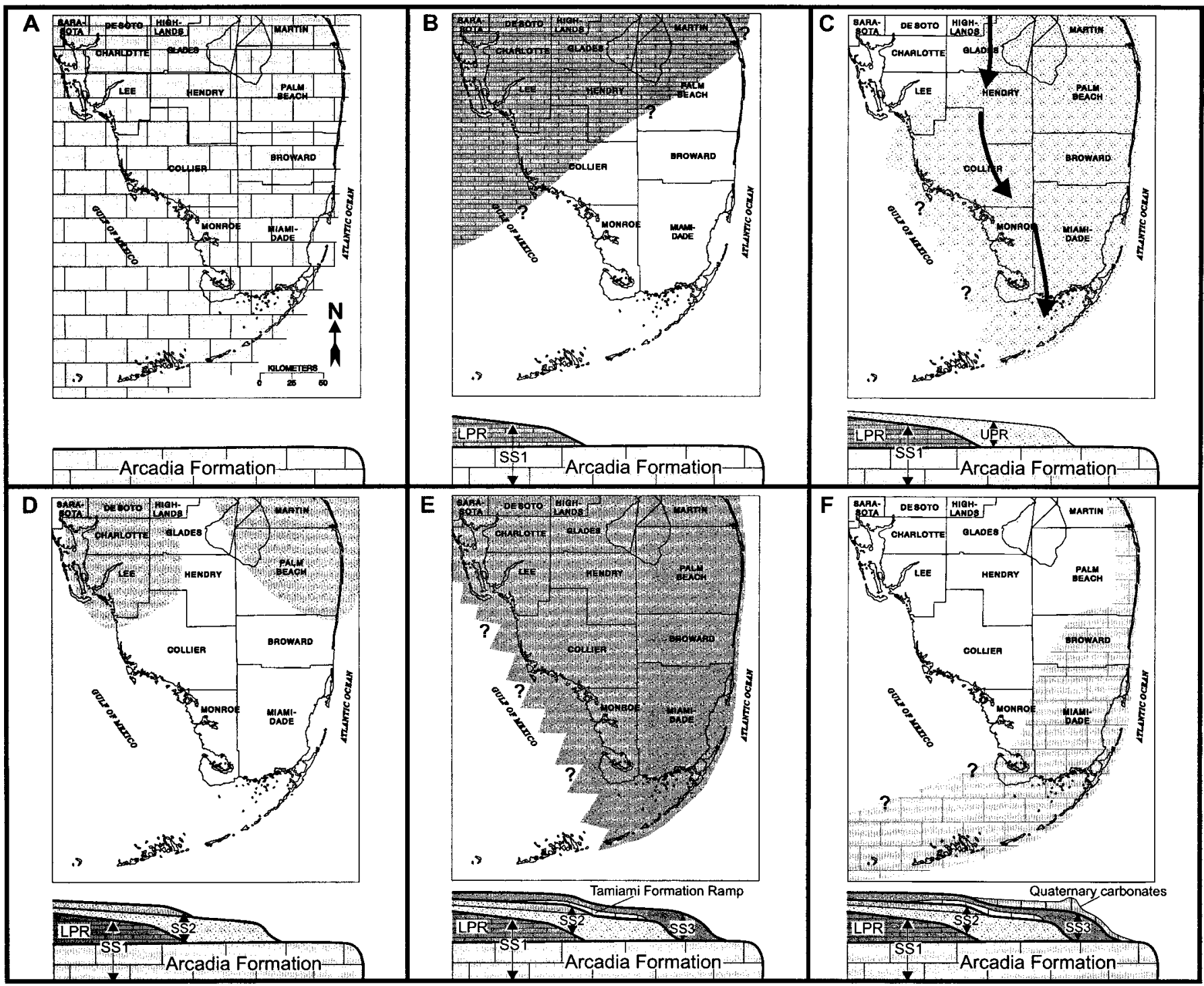

FIg. 10.-Maps of areal extent of successive depositional events in south Florida and cross sections showing progressive stratigraphic development resulting from synthesis of work from this study, Puri and Vernon (1965), Hoffmeister et al. (1967), Enos and Perkins (1977), Warzeski et al. (1996), Cunningham et al. (1998), Missimer (1999), Guertin et al. (2000), and Cunningham et al. (2001a). A) Lower part of SS1 or Arcadia Formation. B) Upper part of SS1 or lower Peace River Formation. C) Late Miocene(?) to early Early Pliocene portion of SS2 or upper Peace River Formation. Arrows roughly corresponds to "coarse clastic distribution corridor" of Warzeski et al. (1996; their Fig. 9) and structural low of Cunningham et al. (1998, their Fig. 17B) mapped at the top SS1 or the unconformity that spans the top of the lower Peace River Formation and the top of the Arcadia Formation. D) Early Pliocene portion of SS2 or upper Peace River Formation, E) SS3 or Tamiami Formation. F) Quaternary carbonates of southeastern Florida.

for later rejuvenation of carbonate-platform growth. A similar scenario has been proposed for Late Quaternary siliciclastics and carbonates along the Belize margin (Ferro et al. 1999). There, Ferro et al. (1999) proposed that initiation and growth of carbonates over shelf-edge siliciclastic delta and slope fan prograding wedges have served as a possible substratum over which the present barrier reef developed. Like the Belize margin, the southeastern Florida Platform is an ideal location to sharpen our understanding of the influence of mixing of siliciclastics and carbonates on platform evolution.

\section{CONCLUSIONS}

High-resolution seismic-reflection data from the Caloosahatchee River have been correlated to lithostratigraphy, nannofossil biostratigraphy, and strontium-isotope chemostratigraphy from six continuously cored boreholes drilled along the bank of the river. Three seismic sequences were identified from correlation of seismic stratal packages to lithofacies changes and unconformities in cores, and corroborated with the chronostratigraphic data. The seismic sequences document a Middle to Late Cenozoic (1) cessation in carbonate-ramp sedimentation on the southeastern part of the Florida Platform, (2) subaerial erosion of the ramp, (3) flooding of the exposure surface during an approximate $100 \mathrm{~m}$ relative rise in sea level, (4) filling of resulting accommodation by siliciclastics, and (5) return to carbonateplatform growth. The seismic and core data provide new evidence that a large Miocene to Early Pliocene fluvial-deltaic system delivered an enormous supply of siliciclastics that accumulated on the southeastern part of the Florida Platform. Recognition of evidence for a fluvial-deltaic system is an important contribution to a long debate about the transport mechanism of these quartz sands, since their early reporting by Vaughan (1910). Development of the inferred fluvial-deltaic system was made possible as a 
result of connection of the platform top to a continental source of sediments and infilling of significant paleotopography. We infer that the substantial paleotopography must have controlled the dispersal of fluvial sediments across the Florida Platform as far south as the present-day shelf edge of the shallow Quaternary carbonate shelf of the Florida Keys. The southward progradation of the Late Tertiary siliciclastics was critical to recovery of carbonate growth on the southeastern Florida Platform that ceased during the Miocene. Had these quartz sands not filled accommodation near the southeastern edge of the Florida Platform it is likely that the return to shallow-marine carbonate deposition as a reef-rimmed shelf during the Quaternary would not have occurred. This work shows that the southeastern Florida Platform is an ideal location to refine our understanding of the influence of the mixing of siliciclastics and carbonates on platform evolution.

\section{ACKNOWLEDGMENTS}

Clyde Dabbs and Eric Swain are thanked for initiating the project. The U.S. Geological Survey and the South Florida Water Management District cooperatively funded this research. Jim Trindell, FGS, expertly drilled the coreholes. Robert Renken, Jack Kindinger, and Tom Scott provided early technical reviews. Steve Goodbred, Michael Blum, David Budd, and an anonymous reviewer are thanked for final critical reviews. Anthony Brown assisted with collection of field data.

\section{REFERENCES}

ALt, D., 1974, Arid climate control of Miocene sedimentation and origin of modern drainage, southeastern United States, in Oaks, R.Q., Jr., and Dunbar, J.R., eds., Post-Miocene Stratigraphy, Central and Southern Atlantic Coastal Plain: Logan, Utah, Utah State University Press, p. 21-29.

Applin, P.L., And Applin, E.R., 1965, The Comanche Series and associated rocks in the subsurface in central and south Florida: U.S. Geological Survey, Professional Paper 447, p. 184.

BARRON, J.A., 1992, Neogene diatom datum levels in the equatorial and North Pacific, in Ishizaki, K., and Saito, T., eds., The Centenary of Japanese Micropaleontology: Tokyo, Terra Scientific Publishing Company, p. 413-426.

Barron, J.A., Bukry, D., And Poore, R.Z., 1984, Correlation of the middle Eocene Kellog Shale of northern California: Micropaleontology, v. 30, p. 138-170.

Berggren, W.A., Kent, D.V., Swisher, C.C., III, And Aubry, M.-P., 1995, A revised Cenozoic geochronology and chronostratigraphy, in Berggren, W.A., Kent, D.V., Aubry, M.-P., and Hardenbol, J., eds., Geochronology, Time Scales and Global Stratigraphic Correlation: SEPM, Special Publication 54, p. 129-212.

BisHop, E.W., 1956, Geology and ground water resources of Highlands County, Florida: Florida Geological Survey, Report of Investigations 15, 113 p.

Bock, W.D., Lynts, G.W., Smith, S., Wright, R., Hay, W.W., ANd Jones, J.I., 1971, A symposium of Recent South Florida Foraminifera: Miami Geological Society, Memoir 1, 245 p.

Brewster-Wingard, G.L., Scott, T.M., Edwards, L.E., Weedman, S.D., and Simmons, K.R., 1997, Reinterpretation of the peninsular Florida Oligocene: an integrated stratigraphic approach: Sedimentary Geology, v. 108, p. 207-228.

Bukry, D., 1991, Paleoecological transect of western Pacific Ocean late Pliocene coccolith flora: Part I-Tropical Ontong-Java Plateau at ODP 806B: U.S. Geological Survey, OpenFile Report 91-552, 35 p.

Chen, C.S., 1965, The regional lithostratigraphic analysis of Paleocene and Eocene rocks of Florida: Florida Geological Survey, Bulletin 45, p. 1-105.

Chol, D.R., And Ginsburg, R.N., 1982, Siliciclastic foundations of Quaternary reefs in the southernmost Belize Lagoon, British Honduras: Geological Society of America, Bulletin, v 93 , p. $116-126$.

ChoI, D.R., And Holmes, C.W., 1982, Foundations of Quaternary reefs in South Central Belize Lagoon, Central America: American Association of Petroleum Geologists, Bulletin, v. 66, p. 2663-2681.

Cunningham, K.J., Bukry, D., Sato, T., Barron, J.A., Guertin, L.A., and Reese, R.S., 2001a, Lithostratigraphy, sequence stratigraphy and biostratigraphy of a carbonate ramp and bounding siliciclastics (Late Miocene-Pliocene), southern Florida: Florida Geological Survey, Special Publication 49, p. 35-66.

Cunningham, K.J., Locker, S.D., Hine, A.C., Bukry, D., Barron, J.A., and Guertin, L.A., 2001b, Surface-geophysical characterization of ground-water systems of the Caloosahatchee River Basin, southern Florida: U.S. Geological Survey, Water-Resources Investigations Report 01-4084, $76 \mathrm{p}$

Cunningham, K.J., McNeill, D.F., Guertin, L.A., Ciesielski, P.F., Scott, T.M., and de Verteuil, L., 1998, New Tertiary stratigraphy for the Florida Keys and southern peninsula of Florida: Geological Society of America, Bulletin, v. 110, p. 231-258.

Davis, J.L., AND ANNAN, A.P., 1989, Ground penetrating radar for high resolution mapping of soil and rock stratigraphy: Geophysical Prospecting, v. 37, p. 531-551.

Davies, P.J., Symonds, P.A., Feary, D.A., and Pigram, C.J., 1989, The evolution of the carbonate platforms of northeastern Australia, in Crevello, P.D., Wilson, J.L., Sarg, J.F., and
Read, J.F., eds., Controls on Carbonate Platform and Basin Development: SEPM, Special Publication 44, p. 233-258.

Denny, W.M., III, Austin, J.A., JR., AND Buffler, R.T., 1994, Seismic stratigraphy and geologic history of Middle Cretaceous through Cenozoic rocks, southern Straits of Florida: American Association of Petroleum Geologists, Bulletin, v. 78, p. 461-487.

Dobkins, J.E., JR., AND Folk, R.L., 1970, Shape development on Tahiti-Nui: Journal of Sedimentary Petrology, v. 40, p. 1167-1203.

Edwards, L.E., Weedman, S.D., Simmons, K.R., Scott, T.M., Brewster-Wingard, G.L., Ishman, S.E., AND CARLIN, N.M., 1998, Lithostratigraphy, petrography, biostratigraphy, and strontium-isotope stratigraphy of the surficial aquifer system of western Collier County, Florida: U.S. Geological Survey, Open-File Report 98-205, 79 p.

Enos, P., AND PERKIns, R.D., EDS., 1977, Quaternary Sedimentation in South Florida: Geological Society of America, Memoir 147, $198 \mathrm{p}$

Evans, M.W., AND Hine, A.C., 1991, Late Neogene sequence stratigraphy of a carbonatesiliciclastic transition: Geological Society of America, Bulletin, v. 103, p. 679-699.

Ferro, C.E., Droxler, A.W., Anderson, J.B., And Mucciarone, D., 1999, Late Quaternary shift of mixed siliciclastic-carbonate environments induced by glacial eustatic sea-level fluctuations in Belize, in Harris, P.M., Saller, A.H., and Simo, J.A., eds., Advances in Carbonate Sequence Stratigraphy; Applications to Reservoirs, Outcrops and models: SEPM, Special Publication 63, p. 383-411.

GinsbuRG, R.N., Brown, K.M., And Chung, G.S., 1989, Siliciclastic foundations of South Florida's Quaternary carbonates (abstract): Geological Society of America, Abstracts with Programs, v. 21, p. A-290.

Guertin, L.A., McNeill, D.F., Lidz, B.H., and Cunningham, K.J., 1999, Chronologic model and transgressive-regressive signatures in the late Neogene siliciclastic foundation (Long Key Formation) of the Florida Keys: Journal of Sedimentary Research, v. 69, p. 653-666.

Guertin, L.A., Missimer, T.M., and McNeill, D.F., 2000, Hiatal duration of correlative sequence boundaries from Oligocene-Pliocene mixed carbonate/siliciclastic sediments of the south Florida Platform: Sedimentary Geology, v. 134, p. 1-26.

Hammes, U., 1992, Sedimentation patterns, sequence stratigraphy, cyclicity, and diagenesis of Early Oligocene carbonate ramp deposits, Suwannee Formation, southwest Florida, U.S.A., [unpublished Ph.D. thesis]: University of Colorado, Boulder, Colorado, 344 p.

HaQ, B.U., Hardenbol, J., and Vail, P.R., 1988, Mesozoic and Cenozoic chronostratigraphy and cycles of sea-level change, in Wilgus, C.K., Hastings, B.S., Kendall, C.G.St.C., Posamentier, H.W., Ross, C.A., and Van Wagoner, J.C., eds., Sea Level Changes-An Integrated Approach: SEPM, Special Publication 42, p. 72-108.

HINE, A.C., 1997, Structural and paleoceanographic evolution of the margins of the Florida Platform, in Randazzo, A.F., and Jones, D.S., eds., Geology of Florida: Gainesville, Florida, University Press of Florida, p. 169-194.

Hoffmeister, J.E., Stockman, K.W., and Multer, H.G., 1967, Miami Limestone of Florida and its recent Bahamian counterpart: Geological Society of America, Bulletin, v. 78, p. 175 190

HowarTh, R.J., AND McArthur, J.M., 1997, Statistics for strontium isotope stratigraphy: a robust LOWESS fit to the marine Sr-isotope curve for 0 to $206 \mathrm{Ma}$, with look-up table for derivation of numeric age: Journal of Geology, v. 105, p. 441-456.

Hull, J.P.D., 1962, Cretaceous Suwannee Strait, Georgia and Florida: American Association of Petroleum Geologists, Bulletin, v. 18, p. 118-122.

JoNES, R.W., 1994, The Natural History Museum, London, The Challenger Foraminifera: New York, Oxford University Press, 149 p.

Jordan, G.F., Malloy, R.J., and Kofoed, J.W., 1964, Bathymetry and geology of the Pourtales Terrace, Florida: Marine Geology, v. 1, p. 259-287.

Kane, B.C., 1984, Origin of the Grandin Sands (Plio-Pleistocene), western Putnam County, Florida [unpublished M.S. thesis]: University of Florida, Gainesville, Florida, 85 p.

Klein, H.B., Schroeder, M.C., AND LichtLer, W.F., 1964, Geology and ground water resources of Glades and Hendry Counties: Florida Geological Survey, Report of Investigations No. $37,132 \mathrm{p}$

Kolb, C.R., and VAN LopiK, J.R., 1966, Depositional environments of the Mississippi River deltaic plain, southeastern Louisiana, in Shirley, M.L., and Ragsdale, J.A., eds., Deltas: Houston, Texas, Houston Geological Society, p. 17-62.

McKinney, M.L., 1984, Suwannee Channel of the Paleogene coastal plain: Support for the carbonate suppression model of basin formation: Geology, v. 12, p. 343-345.

Meyer, F.O., 1989, Siliciclastic influence on Mesozoic platform development: Baltimore Canyon Trough, western Atlantic, in Crevello, P.D., Wilson, J.L., Sarg, J.F., and Read, J.F., eds., Controls on Carbonate Platform and Basin Development: SEPM, Special Publication 44 , p. $212-232$

Missimer, T.M., 1992, Stratigraphic relationships of sediment facies within the Tamiami Formation of southwestern Florida: proposed intraformational correlations, in Scott, T.M., and Alman, W.D., eds., The Plio-Pleistocene Stratigraphy and Paleontology of Southern Florida: Florida Geological Survey, Special Publication 36, p. 63-92.

Missimer, T.M., 1997, Late Oligocene to Pliocene evolution of the central portion of the South Florida Platform: Mixing of siliciclastic and carbonate sediments [unpublished Ph.D. thesis] University of Miami, Coral Gables, Florida, 2 volumes, 406 and 587 p.

Missimer, T.M., 1999, Sequence stratigraphy of the Late Miocene-Early Pliocene Peace River Formation, Southwestern Florida: Gulf Coast Association of Geological Societies, Transactions, v. 49, p. 358-368.

Missimer, T.M., AND GARDNER, R.A., 1976, High-resolution seismic reflection profiling for mapping shallow water aquifers in Lee County, Florida: U.S. Geological Survey, WaterResources Investigation 76-45, $30 \mathrm{p}$

Mitchum, R.M., JR., Vail, P.R., And Sangree, J.B., 1977, Seismic stratigraphy and global changes of sea level, part 6: stratigraphic interpretation of seismic reflection patterns in depositional sequences, in Payton, C.E., ed., Seismic Stratigraphy-Applications to Hydro- 
carbon Exploration: American Association of Petroleum Geologists, Memoir 26, p. 117 133.

Mullins, H.T., Gardulski, A.F., Hine, A.C., Allan, J.M., Wise, S.W., JR., and Applegate, J., 1988, Three-dimensional sedimentary framework of the carbonate ramp slope of central west Florida: A sequential seismic stratigraphic perspective: Geological Society of America, Bulletin, v. 100, p. 514-533.

Mullins, H.T., Gardulski, A.F., Wise, S.W., JR., and Applegate, J., 1987, Middle Miocene oceanographic event in the eastern Gulf of Mexico: implications for seismic stratigraphic succession and Loop Current/Gulf Stream circulation: Geological Society of America Bulletin, v. 98, p. 702-713.

Murray, J.W., 1991, Ecology and Palaeoecology of Benthic Foraminifera: Essex, U.K., Longman Scientific \& Technical, 397 p.

OKADA, H., AND BuKRY, D., 1980, Supplementary modification and introduction of code numbers to the low-latitude coccolith biostratigraphic zonation: Marine Micropaleontology, v. 5, p. 321-325.

PeAcock, R., 1983, The post-Eocene stratigraphy of southern Collier County, Florida: South Florida Water Management District, Technical Publication 83-5, $42 \mathrm{p}$

Peck, D.M., Missimer, T.M., Slater, D.H., Wise, S.W., and O’Donnell, T.H., 1979, Late Miocene glacio-eustatic lowering of sea level: Evidence from the Tamiami Formation of South Florida: Geology, v. 7, p. 285-288.

PoAG, C.W., 1981, Ecologic Atlas of Benthic Foraminifera of the Gulf of Mexico: New York, Academic Press, 174 p.

PoAG, C.W., 1991, Rise and demise of the Bahama-Grand Banks gigaplatform, northern margin of the Jurassic proto-Atlantic seaway: Marine Geology, v. 102, p. 63-130.

Popenoe, P., Henry, V.J., And IdRIs, F.M., 1987, Gulf Trough-The Atlantic connection: Geology, v. 15 , p. 327-332.

Puri, H.S., AND Vernon, R.O., 1965, Summary of the geology of Florida and a guidebook to the classic exposures: Florida Geological Survey, Special Publication 5, 312 p.

Read, J.F., 1985, Carbonate platform facies models: American Association of Petroleum Geologists, Bulletin, v. 64, p. 1575-1612.

Riggs, S.R., 1979, Phosphorite sedimentation in Florida—a model phosphogenic system: Economic Geology, v. 74, p. 285-314.
Schlager, W., 1981, The paradox of drowned reefs and carbonate platforms: Geological Society of America, Bulletin, v. 92, p. 197-211.

Scotт, T.M., 1988, The lithostratigraphy of the Hawthorn Group (Miocene) of Florida: Florida Geological Survey, Bulletin 59, 148 p.

Shipboard Scientific Party, 1998, Explanatory notes, in Norris, R.D., et al., Proceedings of the Ocean Drilling Program: Initial Reports 171B: College Station, Texas (Ocean Drilling Program), p. 11-44.

SonNENFELd, M.D., ANd CRoss, T.A., 1993, Volumetric partitioning and facies differentiation within the Permian Upper San Andres Formation of Last Chance Canyon, Guadalupe Mountains, New Mexico, in Loucks, R.G., and Sarg, J.F., eds., Carbonate Sequence Stratigraphy: Recent Developments and Applications: American Association of Petroleum Geologists, Memoir 57, p. 435-474.

Southgate, P.N., Kennard, J.M., Jackson, M.J., O’Brien, P.E., and Sexton, M.J., 1993, Reciprocal lowstand clastic and highstand carbonate sedimentation, subsurface Devonian reef complex, Canning basin, Western Australia, in Loucks, R.G., and Sarg, J.F., eds., Carbonate Sequence Stratigraphy: Recent Developments and Applications: American Association of Petroleum Geologists, Memoir 57, p. 157-179.

Vaughan, T.W., 1910, A contribution to the geologic history of the Florida Plateau, in Papers from the Tortugas Laboratory, v. IV: Carnegie Institution of Washington, Special Publication 133, p. $99-185$.

Warzeski, E.R. Cunningham, K.J., Ginsburg, R.N., Anderson, J.B., and Ding, Z.-D., 1996, A Neogene mixed siliciclastic and carbonate foundation for the Quaternary carbonate shelf, Florida Keys: Journal of Sedimentary Research, v. 66, p. 788-800.

Weedman, S.D., Paillet, F.L., Edwards, L.E., Simmons, K.R., Scott, T.M., Wardlaw, B.R., REESE, R.S., AND BlaiR, J.L., 1999, Lithostratigraphy, geophysics, biostratigraphy, and strontium-isotope stratigraphy of the surficial aquifer system of eastern Collier County and northern Monroe County, Florida: U.S. Geological Survey, Open File Report 99-432, 125 p.

Willard, D.A., Cronin, T.M., Ishman, S.E., and Litwin, R.J., 1993, Terrestrial and marine records of climatic and environmental changes during the Pliocene in subtropical Florida: Geology, v. 21, p. 679-682

WinKER, C.D., AND Howard, J.D., 1977, Plio-Pleistocene paleogeography of the Florida Gulf Coast interpreted from relict shorelines: Gulf Coast Association of Geological Societies, Transactions, v. 27 , p. $409-420$.

Received 2 Ocotber 2001; accepted 24 June 2002. 